Biogeosciences Discuss., 8, 6473-6517, 2011

www.biogeosciences-discuss.net/8/6473/2011/

doi:10.5194/bgd-8-6473-2011

(C) Author(s) 2011. CC Attribution 3.0 License.

\title{
Can Mg isotopes be used to trace cyanobacteria-mediated magnesium carbonate precipitation in alkaline lakes?
}

L. S. Shirokova ${ }^{1,{ }^{*}}$, V. Mavromatis ${ }^{1}$, I. Bundeleva ${ }^{1}$, O. S. Pokrovsky ${ }^{1}$, P. Bénézeth ${ }^{1}$, C. Pearce ${ }^{3}$, E. Gérard ${ }^{2}$, S. Balor ${ }^{4}$, and E. H. Oelkers ${ }^{1}$

${ }^{1}$ Geoscience and Environment Toulouse (GET), UMR5563, CNRS - Observatoire Midi-Pyrénées, 14 Avenue Edouard Belin, 31400 Toulouse, France

${ }^{2}$ Institut de Physique du Globe de Paris, 1 rue Jussieu, 75238 Paris, France

${ }^{3}$ Department of Earth and Environmental Sciences, The Open University, Walton Hall, Milton Keynes, MK7 6AA, UK

${ }^{4}$ Plateau de Microscopie électronique, FRBT CNRS FR3451, Bat. IBCG, 118 route de Narbonne, 31062 Toulouse, France "on leave from: Institute of Ecological Problems of the North, 23 Nab. Sev. Dviny, Russian Academy of Science, Arkhangelsk, Russia

Received: 20 June 2011 - Accepted: 30 June 2011 - Published: 8 July 2011

Correspondence to: O. S. Pokrovsky (oleg@get.obs-mip.fr)

Published by Copernicus Publications on behalf of the European Geosciences Union.

Can $\mathrm{Mg}$ isotopes be used to trace cyanobacteriamediated

L. S. Shirokova et al.

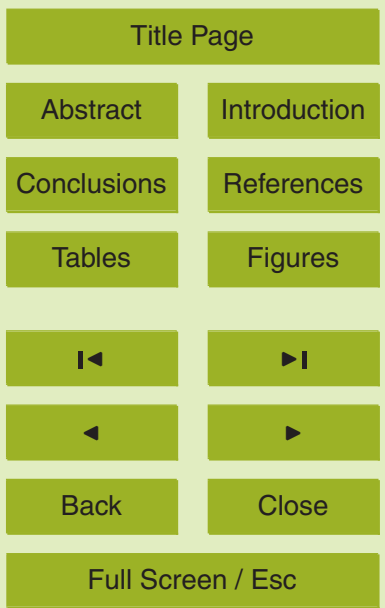

Printer-friendly Version

Interactive Discussion 


\section{Abstract}

The fractionation of $\mathrm{Mg}$ isotopes was determined during the cyanobacterial mediated precipitation of hydrous magnesium carbonate precipitation in both natural environments and in the laboratory. Natural samples were obtained from Lake Salda (SE

5 Turkey), one of the few modern environments on the Earth's surface where hydrous Mg-carbonates are the dominant precipitating minerals. This precipitation was associated with cyanobacterial stromatolites which were abundant in this aquatic ecosystem. Mg isotope analyses were performed on samples of incoming streams, groundwaters, lake waters, stromatolites, and hydromagnesite-rich sediments. Laboratory $10 \mathrm{Mg}$ carbonate precipitation experiments were conducted in the presence of purified Synechococcus sp cyanobacteria that were isolated from the lake water and stromatolites. The hydrous magnesium carbonates nesquehonite $\left(\mathrm{MgCO}_{3} \cdot 3 \mathrm{H}_{2} \mathrm{O}\right)$ and dypingite $\left(\mathrm{Mg}_{5}\left(\mathrm{CO}_{3}\right)_{4}(\mathrm{OH})_{2} 5\left(\mathrm{H}_{2} \mathrm{O}\right)\right)$ were precipitated in these batch reactor experiments from aqueous solutions containing either synthetic $\mathrm{NaHCO}_{3} / \mathrm{MgCl}_{2}$ mixtures or natural Lake

15 Salda water, in the presence and absence of live photosynthesizing Synechococcus $\mathrm{sp}$. Bulk precipitation rates were not to affected by the presence of bacteria when air was bubbled through the system. In the stirred non-bubbled reactors, conditions similar to natural settings, bacterial photosynthesis provoked nesquehonite precipitation, whilst no precipitation occurred in bacteria-free systems in the absence of air bubbling, despite the fluids achieving a similar or higher degree of supersaturation. The extent of $\mathrm{Mg}$ isotope fractionation $\left(\Delta^{26} \mathrm{Mg}_{\text {solid-solution }}\right)$ between the mineral and solution in the abiotic experiments was found to be identical, within uncertainty, to that measured in cyanobacteria-bearing experiments, and ranges from -1.4 to $-0.7 \%$. This similarity refutes the use of $\mathrm{Mg}$ isotopes to validate microbial mediated precipitation of hydrous

\section{BGD}

$8,6473-6517,2011$

Can Mg isotopes be used to trace

cyanobacteriamediated

L. S. Shirokova et al.

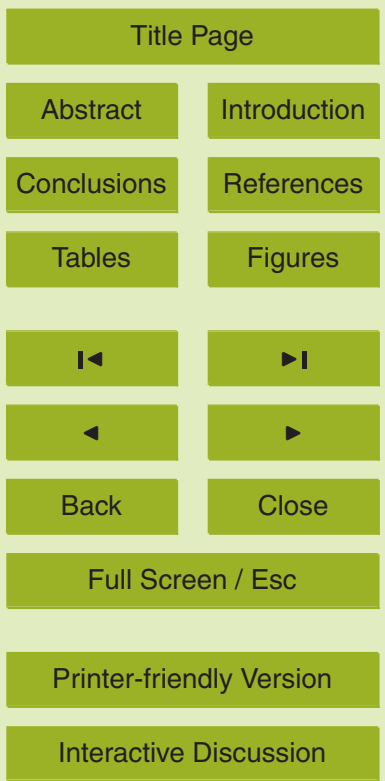




\section{Introduction}

Traditional stable isotopes $(\mathrm{C}, \mathrm{O}, \mathrm{N}, \mathrm{S}, \mathrm{B})$ have been used extensively to elucidate biogeochemical processes in aquatic lacustrine environments (e.g. Pentecost and Spiro, 1990; Peterson and Fry, 1987). The stable isotopic composition of "non-traditional"

5 metals such as $\mathrm{Ca}, \mathrm{Cu}, \mathrm{Fe}, \mathrm{Li}, \mathrm{Mg}, \mathrm{Zn}$ are just starting to be used to understanding the processes operating in lake systems. Of these isotope systems, $\mathrm{Mg}$ is of particular interest because: (1) it is a major component of the lake water; (2) it is an important component of chlorophyll in aquatic microorganisms (Black et al., 2006, 2007); (3) hydrous Mg-minerals are known to form in lake sediments (Castanier et al., 1993; Power et al., 2009), and (4) stable $\mathrm{Mg}$ isotopes fractionate more significantly compared to other alkaline earth metals such as $\mathrm{Ca}$ and Sr (Galy et al., 2002; Tipper et al., 2006; Higgins and Schrag, 2010; Li et al., 2011; Schauble, 2011).

One of the most important processes controlling the biogeochemical cycling of $\mathrm{Mg}$ in continental waters is carbonate biomineralization (Lowenstum and Weiner, 1989; Dove, 2010). Cyanobacteria-induced mineralization has occurred in both ancient and modern environments since the Precambrian (Kempe and Kazmierczak, 1990; Knoll et al., 1993; Brady et al., 2009; Planavsky et al, 2009; Raven and Giordano, 2009; Riding, 2000; Ries, 2010). Most modern freshwater cyanobacteria-dominated carbonate formation is observed in alkaline aquatic environments with high $\mathrm{Ca}$ to $\mathrm{Mg}$ ratios (Scholl and Taft, 1964; Müller et al., 1972; Otsuki and Wetzel, 1974; Kelts and Hsü, 1978; Pentecost, 1978; Stabel, 1986; Thompson and Ferris, 1990; Pedone and Folk, 1996; Ferris et al., 1997; Thompson et al., 1997; Kazmierczak and Kempe, 2006; Dupraz et al., 2009; Power et al., 2011), and produces various calcium carbonate minerals. In contrast, the formation of Mg-rich carbonate minerals by cyanobacteria occurs only in mafic rock weathering products (e.g. Braithwaite and Zedef, 1994), alkaline lakes such as those in British Columbia (Renaut, 1990; Power et al., 2007, 2009), and in some saline lake sediments (Renaut and Long, 1989; Renaut and Douglas, 1990; Queralt et

BGD

$8,6473-6517,2011$

Can Mg isotopes be used to trace

cyanobacteriamediated

L. S. Shirokova et al.

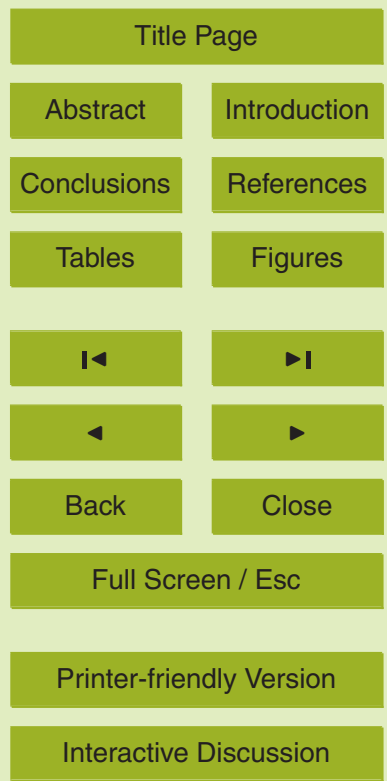


al., 1997). Interest in these $\mathrm{Mg}\left(\mathrm{HCO}_{3}\right)_{2}$-dominated lakes has been recently stimulated by discovery of $\mathrm{Mg}$ carbonates on the surface of the Mars, which may provide evidence for the presence of Mg-rich waters (Calvin et al., 1994; Russell et al., 1999; Edwards et al., 2005; Palomba et al., 2009).

5 The reaction rates and mechanisms of Ca-carbonate precipitation associated with cyanobacterial activity, both in liquid suspension (Hartley et al., 1995, Obst and Dittrich, 2006; Obst et al., 2009; Dittrich and Sibler, 2010; Kranz et al., 2010) and in biofilms (Jorgensen et al., 1983; Cox et al., 1989; Hartley et al., 1996) are relatively well understood. In contrast, the main biological and physico-chemical factors control10 ling hydrous $\mathrm{Mg}$ carbonate precipitation and $\mathrm{Mg}$ isotope fractionation in natural waters are still poorly constrained. In this regard, the alkaline Lake Salda (SW Turkey) represents an excellent natural laboratory where contemporary Mg carbonate precipitation can be studied. Previous studies provided a comprehensive understanding of the geology, lithology, biology, and mineral precipitation processes occurring in the lake magnesite $\left(\mathrm{Mg}_{5}\left(\mathrm{CO}_{3}\right)_{4}(\mathrm{OH})_{2} 4 \mathrm{H}_{2} \mathrm{O}\right)$ microbialites (stromatolites) developed along the lake coast were formed by cyanobacterial and algal activity (Braithwaite and Zedef, 1994). In this study we sampled Lake Salda waters, sediments, and stromatolites and performed laboratory experiments to characterize the range and mechanisms of $\mathrm{Mg}$ fractionation occurring in this lacustrine environment. These results represent the first quantitative experimental and field calibration of $\mathrm{Mg}$ isotope fractionation between the aqueous solution and biotically and abiotically formed hydrous magnesium carbonates under conditions similar to the lake water. As such, these results provide the fundamental basis for using magnesium isotopes as a proxy for tracing biomineral-
BGD

$8,6473-6517,2011$

Can $\mathrm{Mg}$ isotopes be used to trace

cyanobacteriamediated

L. S. Shirokova et al.

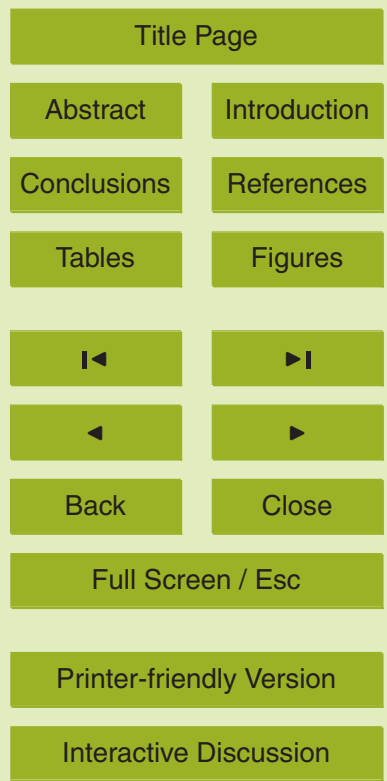




\section{Materials and methods}

\subsection{Site description}

Lake Salda (also known as Salda Gölü in Turkish) is located in SW Turkey and has a surface area close to $45 \mathrm{~km}^{2}$ and an average depth of $80 \mathrm{~m}$, with a maximum reported 5 depth of $200 \mathrm{~m}$ (see Fig. 1a). Its limnology, geology, and geochemistry has been extensively studied (Schmid, 1987; Braithwaite and Zedef, 1994, 1996; Russell et al., 1999; Zedef et al., 2000; Kazanchi et al., 2004). This lake is a natural analogue for mineral carbonation (e.g. Oelkers et al., 2008), as meteoric waters feeding the lake dissolve adjacent ultramafic rocks and precipitate hydromagnesite in shallow littoral zones. This 10 is similar to the process recently documented in the British Columbia playas (Power et al., 2009). The lake has no outlet and the water level varies annually depending on precipitation and evaporation.

Contemporary hydromagnesite stromatolites are developed in the coastal zone (littoral) of the SW part of the lake, known as Kocaadalar Burnu, where they form three 20 to $100 \mathrm{~m}^{2}$ mounds situated $\sim 50 \mathrm{~m}$ offshore and rise $\sim 10 \mathrm{~m}$ from the lake bottom, reaching within 3-4 $\mathrm{m}$ of the lake surface. Similar to Braithwaite and Zedef (1994, 1996), we define all of the modern, actively grown microbialite structures as stromatolites. Underwater diving examination of the deepest part of these mounds showed no evidence of stromatolites below 6-10 m water depth. $1-1.5 \mathrm{~m}^{2}$ stromatolites were found in other parts of the lake within $10-20 \mathrm{~m}$ of the shoreline (see Fig. 1b). Finally, at the littoral of the north side of the lake, most of the submerged stones were covered by actively forming, non-solidified stromatolites (see Fig. 1c) that had the same surface texture as the larger mounds. Detailed underwater examination of the stromatolite surfaces demonstrated that they are alive and actively growing. The mineral surface was covered by a layer of green algae, diatoms, and cyanobacteria with oxygen bubbles adjacent to the surface of the microbial mats (see Fig. 1d).

Can $\mathrm{Mg}$ isotopes be used to trace

cyanobacteriamediated

L. S. Shirokova et al.

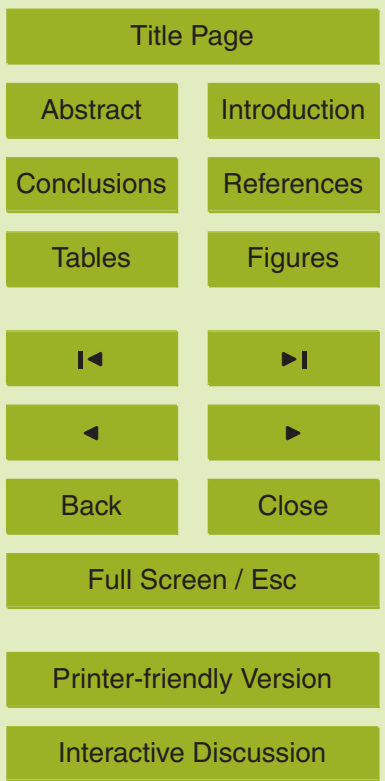




\subsection{Lake water and mineral sampling}

Water samples were taken from inflowing streams and the lake littoral zone in February 2008, February 2010, and September 2010. A profile of the lake water column (down to $70 \mathrm{~m}$ depth) was also collected from the middle of the lake in September 2010 using 5 an Aquatic Research Co. horizontal polycarbonate water sampler, enabling ultraclean sampling in the field (Shirokova et al., 2010). The water samples were immediately filtered through sterile, single-use Sartorius Minisart0.45 $\mu \mathrm{m}$ acetate cellulose filters. The first $100 \mathrm{ml}$ of the filtrate was systematically discarded. Dissolved oxygen, $\mathrm{pH}$, and temperature were measured on-site with an uncertainty of $5 \%, 0.02$ units, and $0.5^{\circ} \mathrm{C}$,

10 respectively. Concentrations of dissolved organic carbon (DOC), $\mathrm{Cl}, \mathrm{SO}_{4}$, alkalinity, cations and trace element (TE) were subsequently measured in the laboratory using methods routinely applied for analysis of lake and river water samples (Pokrovsky et al., 2010, 2011; Shirokova et al., 2010; Vasyukova et al., 2010). From 2 to 5 liters of surface water were also filtered on-site using a sterile Nalgene disposable filter unit 15 and $0.22 \mu \mathrm{m}$ polycarbonate filters. These samples were stored in sterile polypropylene containers and subsequently used for the bacterial culturing. Once filtered, all water samples were stored at $5^{\circ} \mathrm{C}$.

Hydromagnesite samples were collected from the massive stromatolite mounds of Kocaadalar Burnu, other air-exposed stromatolite islands, and parts of stromatolites collected from 4-5 $\mathrm{m}$ depth. We also sampled hydromagnesite sand from the beach and carbonate mineral coatings on submerged branches and grasses. A map of the lake with position of sampling points is given in Electronic Supplementary Material ESM-1.

\subsection{Culture and characterization of cyanobacteria}

25 A culture of Synechoccocus sp. cyanobacteria was isolated from the surface of coastal stromatolites sampled in February 2008 from the depth of $1 \mathrm{~m}$ at $50 \mathrm{~m}$ from the Lake Salda shoreline. Cyanobacterial strains Chroococcus turgidus, Plankothrix, Anabaena,

\section{8}

\section{BGD}

8, 6473-6517, 2011

Can Mg isotopes be used to trace

cyanobacteriamediated

L. S. Shirokova et al.

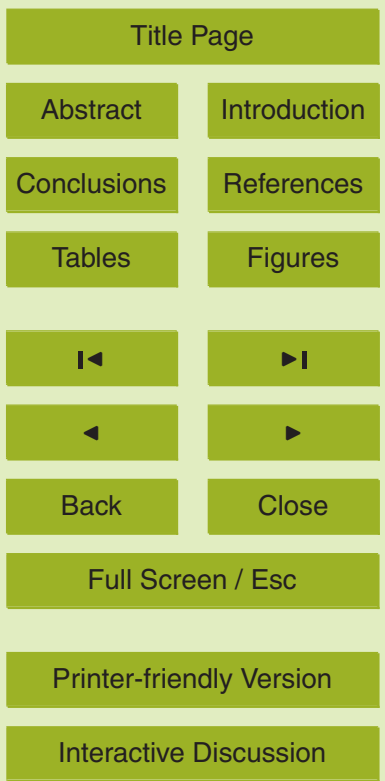


and Microcystis were reported to occur in adjacent $\mathrm{Mg}\left(\mathrm{HCO}_{3}\right)_{2}$-rich alkaline Lake Burdur, SW Turkey (Girgin et al., 2004). The culture was purified on agar BG-11 or Pratt media and individual colonies were grown in synthetic, cyanobacteria BG-11 Freshwater Solution for 3 weeks until the stationary growth phase was attained. Continuous 5 illumination at $2000 \mathrm{~lx}$ was provided from fluorescent lamps. Cyanobacterium Synechoccocus typically consists of isolated elongated cells, without significant mucilage.

The phylogenetic affiliation of the collected and grown cyanobacterium Synechoccocus was performed by DNA extraction (UltraClean ${ }^{\circledR}$ Microbial DNA Isolation Kit $\mathrm{MO} \mathrm{BIO}$ ) and 16S RNA gene amplifying using bacterial-specific primer 27F (5'10 AGAGTTTGATCCTGGCTCAG) and prokaryote-specific reverse primer 1492R (5'GGTTACCTTGTTACGACTT) - see Gerard et al. (2009) for the condition of PCR amplification) and sequencing (Cogenics, Beckman Coulter Genomics). The sequence was then identified by Basic Local Alignment Search Tool (BLAST)against the National Center for Biotechnology Information (NCBI) non-redundant nucleotides database. We found that the purified culture and Synechoccocus sp. PCC 6312, already reported to occur in alkaline lakes and notably Lake Salda (Girgin et al., 2004), share $96 \%$ their 16S RNA genes. The concentration of the bacterial cell suspensions was quantified via optical density (O.D.) using a spectrophotometer at a wavelength of $750 \mathrm{~nm}$ (Hu et al., 2000; Sarcina and Mullineaux, 2000). The O.D. calibration curve - wet weight was linear up to 1.3 absorbance units and the ratio between wet and freeze-dried weight of Synechoccocus sp. was $8.0 \pm 2.0$.

A similar cyanobacteria culture was isolated from the interior part of the stromatolite and from the algal coating on submerged branches in inflowing stream. As such, this culture can be viewed as representative of the Lake Salda peryphyton. Note that other cyanobacterial species like Gloeocapsa sp. were also reported to occur in Lake Salda stromatolites and its water column (Braithwaite and Zedef, 1994). Therefore, several experiments on the Salda Lake water were performed using a previously described model Gloeocapsa sp. culture (Pokrovsky et al., 2008; Mavromatis et al., 2011).
BGD

$8,6473-6517,2011$

Can $\mathrm{Mg}$ isotopes be used to trace

cyanobacteriamediated

L. S. Shirokova et al.

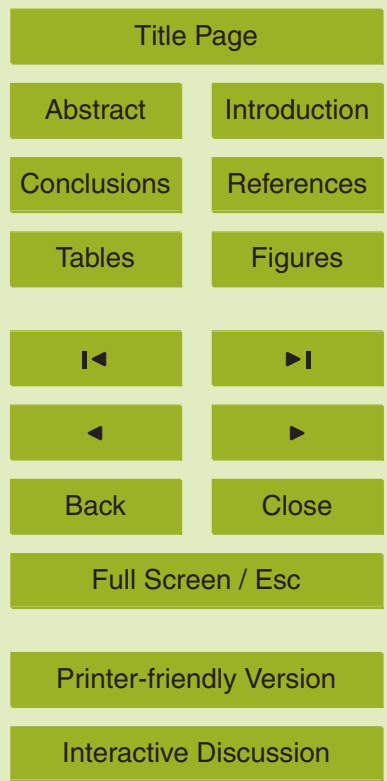




\subsection{Laboratory precipitation experiments}

Laboratory experiments were aimed at precipitating hydrous $\mathrm{Mg}$ carbonates in the presence of the cyanobacterial cultures extracted from the Lake Salda stromatolites under controlled conditions. Experiments were performed in $1000 \mathrm{ml}$ sterile borosil5 icate glass reactors. Two distinct fluid phases were used in the experiments. One is a low-phosphate Cyanobacteria BG-11 freshwater solution medium (Sigma-Aldrich C3061, Rippka et al., 1979); this fluid had the same composition as the BG-11 growth medium other than for its phosphate concentration, which was $50 \mu \mathrm{M}$ or $10 \%$ that of the traditional BG-11. The second was the cell supernatant (sterile filtered BG-11 media after 14-30 days of culture growth during the stationary phase), into which 0.025 $0.030 \mathrm{M} \mathrm{MgCl}_{2}$ and $\sim 0.05 \mathrm{M} \mathrm{NaHCO}_{3}$ were added. In addition, sterile Lake Salda water, $(0.014 \mathrm{M} \mathrm{Mg}, 0.03 \mathrm{MDIC})$ amended with low-phosphate BG-11 nutrient components, was used for additional bacterial growth experiments. A summary of these reactive fluid compositions is provided in Table 1.

Several distinct types of biotic experiments were performed at $25 \pm 2{ }^{\circ} \mathrm{C}$. Experiments S-Bio-2, S-Bio-5, and S-Bio-7 were performed in reactors that were continuously stirred with a magnetic stirring bar and bubbled with sterile humid air with an average flow rate of $1.5 \pm 0.3 \mathrm{~L} / \mathrm{min}$. Experiments S-Bio-1, S-Bio-3, S-Bio-4, and S-Bio-6 were performed in reactors that were stirred, but without air bubbling. Experiments S-Bio-8, S-Bio-9, and S-Bio-10 were run without shaking and bubbling. Each of these experiments was performed under continuous fluorescent light of $30 \mu \mathrm{mol}$ photon $\mathrm{m}^{-2} \mathrm{~s}^{-1}$.

Abiotic, cell-free control experiments were also performed at a variety of conditions. Experiment S-Abio-1 was performed with stirring and air bubbling in the presence of a sterile supernatant of the Synechoccocus sp. cyanobacteria containing $50 \pm 10 \mathrm{mg} \mathrm{I}^{-1}$ of dissolved organic carbon (DOC) in the form of cell exometabolites in which $\mathrm{MgCl}_{2}$ and $\mathrm{NaHCO}_{3}$ were added in concentrations similar to those of the biotic experiments. The supernatant solution used in these abiotic experiments was generated after centrifugation and filtration through a $0.22 \mu \mathrm{m}$ sterile filter of the Synechoccocus sp. culture
BGD

$8,6473-6517,2011$

Can Mg isotopes be used to trace

cyanobacteriamediated

L. S. Shirokova et al.

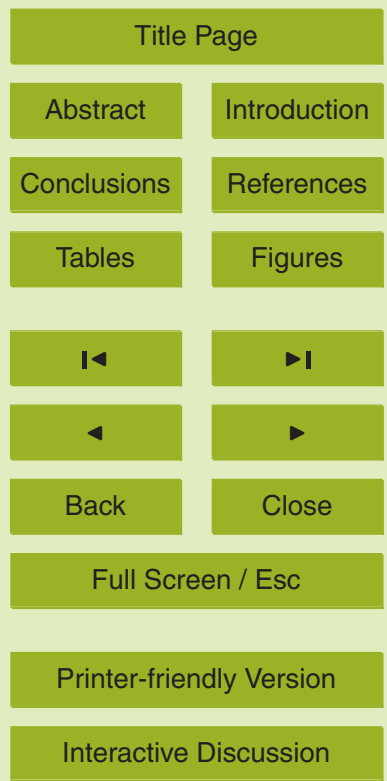


collected $\sim 20$ days after attainment of the stationary phase. Abiotic control experiments S-Abio-2, S-Abio-5, and S-Abio-6 were performed without air bubbling in sterile Lake Salda water amended with low-phosphate BG-11 culture media. Experiment SAbio-4 was performed without air bubbling in a solution having elevated concentrations 5 of $\mathrm{Mg}$ and alkalinity $\left(0.05 \mathrm{M} \mathrm{MgCl}_{2}+0.1 \mathrm{M} \mathrm{NaHCO}_{3}\right)$. All abiotic experiments were performed in the presence of $0.01 \mathrm{M} \mathrm{NaN}_{3}$ to prevent potential microbial growth.

One additional experiment, S-f, was run to assess Mg consumption and isotopic fractionation by Synechoccocus sp. without carbonate precipitation. This experiment was performed in the absence of dissolved $\mathrm{MgCl}_{2}$ and $\mathrm{NaHCO}_{3}$ and Synechoccocus $10 \mathrm{sp}$. was grown in BG-11 medium. The fluid phase and biomass in this experiment was sampled after 5 days and 3 months of growth.

\subsection{Sampling and analyses}

30-50 $\mathrm{ml}$ aliquots of the homogeneous suspension (containing the fluid, precipitated mineral phase, and cells if present) were sampled periodically from the reactors in a 15 sterile laminar hood box. The optical density and $\mathrm{pH}$ were measured in liquid subsamples, whilst the solution supernatants were initially filtered, using $0.22 \mu \mathrm{m}$ filters, and used for alkalinity, DOC, and Mg concentration measurements. Trace elements were measured without preconcentration by ICP-MS (e.g., Pokrovsky et al., 2010, 2011). Alkalinity was determined by $\mathrm{HCl}$ titration using an automatic Schott TitroLine 20 alpha TA10 ${ }^{\text {plus }}$ titrator with an uncertainty of $\pm 2 \%$ and a detection limit of $5 \times 10^{-5} \mathrm{M}$. The DOC content was determined using a Shimadzu TOC-6000 SCN Carbon Total Analyzer with an uncertainty of $3 \%$ and a detection limit of $40 \mu \mathrm{M}$. Magnesium concentrations were measured by flame atomic absorption spectroscopy using a Perkin Elmer AAnalyst 400 with an uncertainty of $\pm 2 \%$ and a detection limit of $0.2 \mu \mathrm{M}$. pH 25 was measured using a Mettler Toledo combined electrode, with a precision of \pm 0.01 . The uncertainty of biomass concentration determination via optical density is estimated to be $\pm 10 \%$.

\section{BGD}

8, 6473-6517, 2011

Can Mg isotopes be used to trace

cyanobacteriamediated

L. S. Shirokova et al.

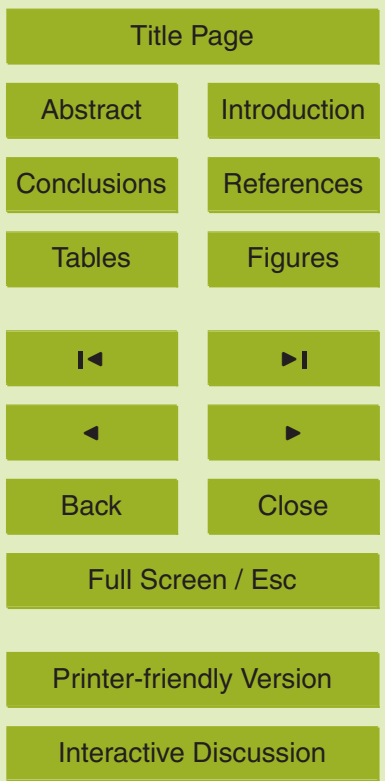


Prior to sample characterization by Scanning Electron Microscopy (SEM), organic matter was removed from the solid phases by treating them with $10 \% \mathrm{H}_{2} \mathrm{O}_{2}$ for $2-3$ days at the same $\mathrm{pH}$ as the experimental fluids. The residual solids were then thoroughly rinsed with de-ionized water and freeze dried at $-55^{\circ} \mathrm{C}$. The mineral phases

5 were then characterized using a Jeol JSM840a SEM, and an INEL CPS 120 X-ray diffractometer using $\mathrm{Co}_{\kappa \alpha}$, with a scan speed of $0.02^{\circ} \mathrm{s}^{-1}$. Untreated solids were kept for chemical analysis as described below.

Transmission Electron Microscopy (TEM) analysis was performed using the TEMSCAN facilities of the University of Toulouse, with a JEOL JEM 2100F unit equipped o with a field emission gun (FEG) source and a PGT EDX detector. TEM samples for analyses were prepared by immersing 200 mesh copper grids coated with a carbon film for $10 \mathrm{~s}$ in solutions containing live bacteria taken from the experiments that either produced or did not produce mineral precipitates. To minimize the potential effect of crystallization from salts present in reactor solutions on TEM/EDX measurements, $20 \mathrm{ml}$ aliquots were centrifuged at $4000 \mathrm{rpm}$ for $10 \mathrm{~min}$ and washed twice with sterile MilliQ water. Grids were dried and covered with a $20 \mathrm{~nm}$ carbon layer prior to TEM analysis.

\subsection{Magnesium isotope analyses}

The Mg isotope compositions of liquid and solid samples collected in the field and pro20 duced during laboratory experiments were analyzed according to the procedure described by Mavromatis et al. (2011). Magnesium isotopic ratios were measured using a Thermo-Finnigan "Neptune" Multi Collector Inductively Coupled Plasma Mass Spectrometer (MC-ICP-MS) at the GET (Toulouse, France). Instrumental mass fractionation effects were corrected via sample-standard bracketing, and all results are presented in 25 delta notation with respect to the DSM-3 international reference material (Galy et al., 2001):

\section{BGD}

8, 6473-6517, 2011

Can Mg isotopes be used to trace

cyanobacteriamediated

L. S. Shirokova et al.

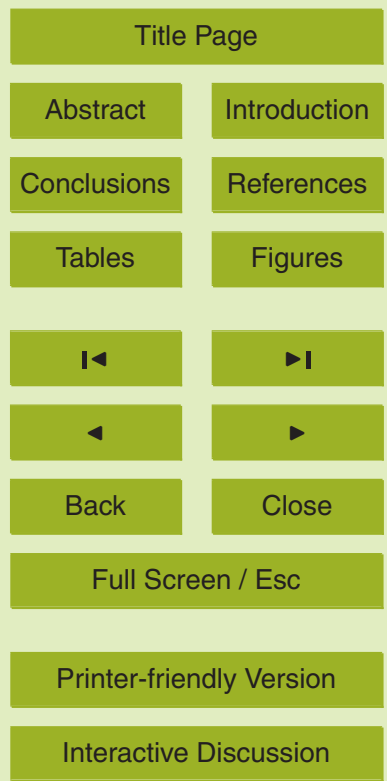


$\delta^{x} \mathrm{Mg}=\left(\frac{\left(\frac{{ }^{x} \mathrm{Mg}}{{ }^{24} \mathrm{Mg}}\right)_{\text {sample }}}{\left(\frac{{ }^{x} \mathrm{Mg}}{{ }^{24} \mathrm{Mg}}\right)_{\mathrm{DSM} 3}}-1\right) \cdot 1000$

BGD

$8,6473-6517,2011$

where $x$ refers to the Mg mass of interest. The reproducibility of these $\delta^{26} \mathrm{Mg}$ analyses was typically $<0.08 \%$ and was confirmed by replicate analyses of three international $\mathrm{Mg}$ reference standards (DSM-3, CAM-1 and OUMg). The isotopic offset between the

$5 \mathrm{Mg}$ in the fluid and that incorporated into the solid phase is defined as:

$\Delta^{26} \mathrm{Mg}_{\text {solid-liquid }} \equiv \delta^{26} \mathrm{Mg}_{\text {solid }}-\delta^{26} \mathrm{Mg}_{\text {liquid }}$

This value was determined for all samples where both the fluid and solid phases were collected in the present study.

\section{Results}

\subsection{Chemical and Mg isotopic composition of Lake Salda water and minerals}

\subsection{Hydrochemistry}

The major and trace element compositions of all collected samples are listed in the Electronic Supplementary Material (ESM) 1. The Mg concentration, alkalinity, and $\mathrm{pH}$ values measured in Lake Salda waters and inflowing streams are in general in agreement with values reported by Braithwaite and Zedef $(1994,1996)$ and Kazanci et al. (2004). In February 2008 and February 2010, the surface water temperature was around $8-10^{\circ} \mathrm{C}$ whereas in September 2010 , it varied from $27.5^{\circ} \mathrm{C}$ at the surface to $13^{\circ} \mathrm{C}$ at $70 \mathrm{~m}$ depth. The most significant stromatolite growth occurs during the summer (Braithwaite and Zedef, 1996) and as such, detailed chemical and isotopic analysis of the lake water composition was performed on water samples collected during September 2010. At this time, $\mathrm{pH}$ decreased from $9.20 \pm 0.05$ at the surface to $9.03 \pm 0.03$

Can $\mathrm{Mg}$ isotopes be used to trace cyanobacteriamediated

L. S. Shirokova et al.

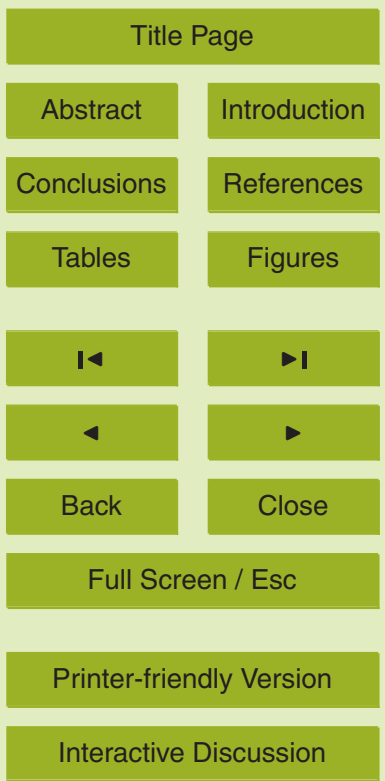


at the bottom of the water column; DOC concentrations ranged from 4.5 to $3.5 \mathrm{mgl}^{-1}$, whilst Alkalinity and $\mathrm{Mg}, \mathrm{Ca}$, and $\mathrm{Cl}$ concentrations remained constant in the water column and were equal to $0.032 \pm 0.001 \mathrm{moll}^{-1}, 390 \pm 5 \mathrm{mgl}^{-1}, 4.0 \pm 0.1 \mathrm{mgl}^{-1}$ and $195 \pm 5 \mathrm{mg} \mathrm{I}^{-1}$, respectively. The Mg concentration of incoming streams and groundwa5 ters was $\sim 3$ times lower than the lake water, and were thereby strongly undersaturated with respect to nesquehonite.

\subsubsection{Stromatolite mineralogy}

The examined stromatolites were dominated by hydromagnesite, as shown by XRD analysis of multiple spots of a $20 \mathrm{~cm}$-thick representative sample and littoral sediments. 10 The carbonate sand of the littoral zone of the lake (the white deposits shown in Fig. 1a) wad also composed of hydromagnesite as it originated from the wave abrasion of growing stromatolites (Braithwaite and Zedef, 1996). The external stromatolite surface had a typical honeycomb-like structure (see Fig. 2a, b), likely formed by the heterotrophic degradation of cyanobacteria cell which are mineralized within their ExoPolySaccha-

ride (EPS) layers (e.g. Dupraz et al., 2004). Platelets of hydromagnesite were clearly seen in the inner parts of stromatolites, which were not exposed directly to lake water (see Fig. 2d). Similar needle-like habits occur on hydromagnesite covering submerged solids such as tree branches (see Fig. 2c). These crystal forms were commonly observed and they are abundant in all investigated hydromagnesite samples.

20 The imprints of Pyrogira green algae were often recognized by the SEM on stromatolite surfaces (not shown) as these algae efficiently colonized active stromatolite surfaces forming visible air bubbles (see Fig. 1d).

\subsubsection{Mg isotopes}

The $\delta^{26} \mathrm{Mg}$ composition of the water column was homogeneous at the time of sampling 25 (September 2010), and it did not vary between different sites in the littoral zone, or due to the presence of stromatolites (see Table 2). The mean $\delta^{26} \mathrm{Mg}$ composition of
BGD

8, 6473-6517, 2011

Can $\mathrm{Mg}$ isotopes be used to trace

cyanobacteriamediated

L. S. Shirokova et al.

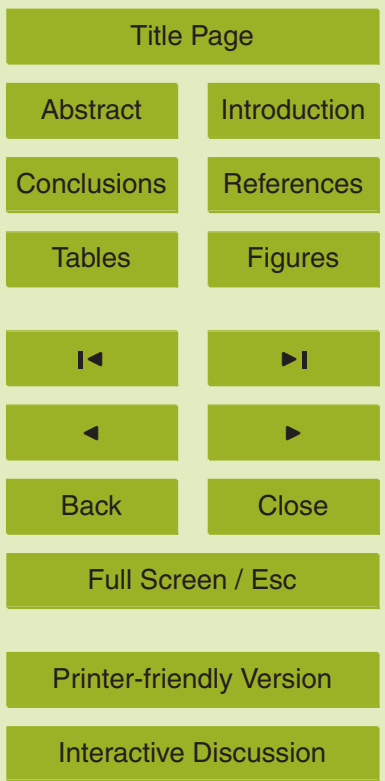


the water column in September 2010 was $0.12 \pm 0.04 \%$, but was found to be slightly lighter at the other sampling times; the mean $\delta^{26} \mathrm{Mg}$ composition of the water found to be -0.005 and $-0.02 \%$ in February 2008 and February 2010 respectively. The incoming spring and ground waters had lighter $\delta^{26} \mathrm{Mg}$ compositions ranging between

$5-1.4$ and $-0.8 \%$. The internal and external parts of stromatolites and the littoral sand exhibited $\delta^{26} \mathrm{Mg}$ composition of $-0.99 \pm 0.07 \%$.

\subsection{Experimental modeling of hydrous Mg carbonate precipitation in laboratory}

The measured chemical composition of the reactive fluids and the mineralogy of precipitated solid phases are listed in the Table ESM-2 of the Electronic Supporting Material

\subsubsection{Solid phases}

X-ray diffraction analysis demonstrated the precipitation of nesquehonite $\left(\mathrm{MgCO}_{3} 3 \mathrm{H}_{2} \mathrm{O}\right)$, dypingite $\left(\mathrm{Mg}_{5}\left(\mathrm{CO}_{3}\right)_{4}(\mathrm{OH})_{2} 5 \mathrm{H}_{2} \mathrm{O}\right)$, and hydromagnesite $\left(\mathrm{Mg}_{5}\left(\mathrm{CO}_{3}\right)_{4}(\mathrm{OH})_{2} 4 \mathrm{H}_{2} \mathrm{O}\right)$ at distinct times during the experiments. Nesquehonite 15 precipitation was limited to the first 12-23 days of experiments S-Bio-2 and S-Bio-5, but it was present after 48 days in experiment S-Abio-4, which was performed in fluids two times more enriched in Mg and DIC. Two biotic experiments (S-Bio-1 and S-Bio-2) yielded brucite at the end of the experiment with nesquehonite followed by dypingite at the beginning. For the majority of the abiotic (S-Abio-1, S-Abio-3) and some biotic experiments (S-Bio-2, S-Bio-3 and S-Bio-5), dypingite or mixtures of dypingite and hydromagnesite, were the main mineral phases present at the end of experiment. Experiments performed on Lake Salda water without air bubbling often yielded hydromagnesite. SEM images (see Fig. 2e-j) revealed that nesquehonite exhibited a needle-like habit (see Fig. 2e), whilst the dypingite was present as 2 to The hydromagnesite was characterized by $0.5-1 \mu \mathrm{m}$ size rounded elongated crystals

BGD

$8,6473-6517,2011$

Can $\mathrm{Mg}$ isotopes be used to trace

cyanobacteriamediated

L. S. Shirokova et al.

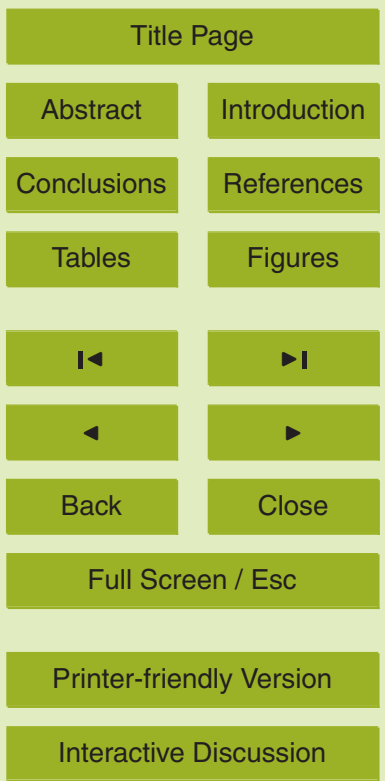


forming large associates (see Fig. $2 \mathrm{~g}$ ). Overall, the sequence of precipitation and recrystallization appears to be: nesquehonite $(20-120 \mu \mathrm{m}$ long, $10 \pm 5 \mu \mathrm{m}$ wide needles, $\rightarrow$ dypingite (5-15 $\mu \mathrm{m}$ rosettes) $\rightarrow$ hydromagnesite 20-40 $\mu \mathrm{m}$ (aggregates).

It is worth noting that the hydromagnesite crystal associates formed in fluids con-

5 taining Gloeocapsa sp. cyanobacteria during experiment S-Bio-8 (see Fig. 2h) were surprisingly similar to the external surface of Lake Salda stromatolites (see Fig. 2a, b), whereas the rosette-like dypingite and hydromagnesite aggregates obtained in experiments with Synechoccocus sp. cyanobacteria during experiment Exp S-Bio-10 (Fig. 2f) and Exp S-Bio-3 (Fig. 2i) were similar to the natural hydromagnesite coatings 10 of submerged surfaces in Lake Salda (see Fig. 2c). Note the shape of hydromagnesite crystals formed in experiment S-Bio-3 (Fig. $2 \mathrm{~g}$ ) was similar to that of coccoid Synechoccocus sp. cyanobacteria (see Fig. 3), suggesting some embedding of the cells. Such an embedding of cells and cell associates was evident in experiment Exp S-Bio11 which was performed with Gloeocapsa sp. cyanobacteria cultured 40 days in $\mathrm{Mg}$, $15 \mathrm{HCO}_{3}$-enriched BG-11 media (see Fig. 2j) and was likely responsible for the typical honeycomb structure of $\mathrm{Mg}$ hydrous carbonates formed in the presence of cyanobacteria (see Fig. $2 \mathrm{~h}$ ) as well as in natural stromatolites (see Fig. 2a, b).

The TEM examination of bacteria grown during 2 weeks in low-phosphate BG-11 nutrient media containing initially $0.025 \mathrm{M} \mathrm{MgCl}_{2}+0.05 \mathrm{M} \mathrm{NaHCO}_{3}$ evidenced the presence of nanometer-size spherulite crystals assembled in network-like 1-2 $\mu \mathrm{m}$ sized associates usually adjacent to the surfaces of live cells (see Fig. $3 a, d, e$ ). In addition, mineral coating of whole cell surfaces (see Fig. $3 c$ ) or cell sheaths (see Fig. 3b) was frequently observed. Cells grown in $\mathrm{Mg}^{2+}, \mathrm{HCO}_{3}^{-}$low nutrient media remained mineral precipitate-free (see Fig. 3f).

\subsubsection{Chemical composition of the fluid phase}

The temporal evolution of $\mathrm{pH}$ and $\mathrm{Mg}$ concentration in all experiments as well as the temporal evolution of alkalinity and biomass concentrations during representative experiments are illustrated in Fig. 4. The $\mathrm{Mg}$ concentration and alkalinity of the reactive

BGD

$8,6473-6517,2011$

Can Mg isotopes be used to trace

cyanobacteriamediated

L. S. Shirokova et al.

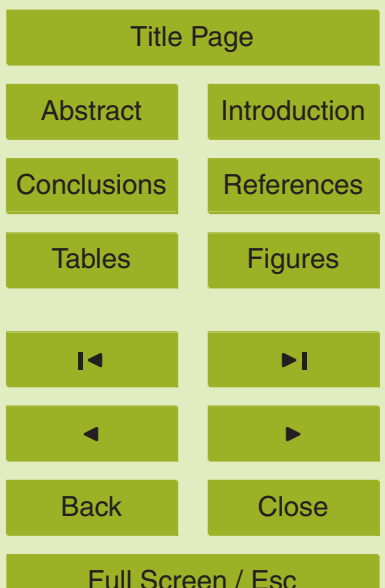

Full Screen / Esc

Printer-friendly Version

Interactive Discussion 
fluids tended to decrease and the $\mathrm{pH}$ tended to increase with time during all biotic experiments, notably those with air bubbling (see Fig. 4a, c, e). Abiotic stirred experiments without air bubbling did not produce a measurable decrease in Mg concentration or alkalinity, although a slight $\mathrm{pH}$ increase was observed (Fig. 4b, d, f). The stirred biotic experiments both with and without air bubbling produced very similar variations in $\mathrm{pH}, \mathrm{Mg}$ concentration, and alkalinity (see Fig. 4), though the biomass production was a factor of two higher in experiments with air bubbling (see Fig. 5). The addition of nutrient BG-11 components to Lake Salda water had a significant effect on biomass production and $\mathrm{Mg}$ hydrous carbonate precipitation, as evident from the decrease in 10 Mg concentration (see Fig. 6).

The mass of precipitated hydrous magnesium carbonate is plotted as a function of the measured biomass present in the reactor fluid in Fig. 7. The line drawn in this figure, consistent with all the results of all experiments containing biomass can be described by:

$\operatorname{Mg}_{\text {precipitated }}($ mmoles $)=(7.1 \pm 0.9) \times$ Biomass $_{\text {produced }}\left(g_{\text {wet }}\right), r^{2}=0.93-0.84$

Converting this relationship into molar scale and taking into account that the ratio of wet to dry biomass of Synechoccocus sp. is $8 \pm 2$ and that the proportion of carbon in dry biomass is $50 \%$ yield the molar inorganic $\mathrm{Mg}$ to organic $\mathrm{C}$ ratio in reaction product of $1.4 \pm 0.2$. This value is compatible with the theoretical $M g / C_{\text {org }}$ ratio of 1 for nesquehonite as first precipitating phase during cyanobacterial photosynthesis:

$\mathrm{Mg}^{2+}+2 \mathrm{HCO}_{3}^{-}+3 \mathrm{H}_{2} \mathrm{O}=\mathrm{MgCO}_{3} \cdot 3 \mathrm{H}_{2} \mathrm{O} \downarrow+\mathrm{CH}_{2} \mathrm{O}+\mathrm{O}_{2} \uparrow$

The speciation and saturation state of the reactive fluids with respect to potentially precipitating mineral phases for all experiments was calculated using PHREEQC software together with its MINTEQA2 database (Parkhurst and Appelo, 1999). The speciation aqueous $\mathrm{Mg}$ during the experiments was dominated by aqued contained significant concentrations of $\mathrm{MgCO}_{3}^{-}(\mathrm{aq})$ and $\mathrm{MgHCO}_{3}^{\circ}$. The evolution of the saturation state of the reactive fluids during the biotic and abiotic experiments with and

\section{BGD}

$8,6473-6517,2011$

Can Mg isotopes be used to trace

cyanobacteriamediated

L. S. Shirokova et al.

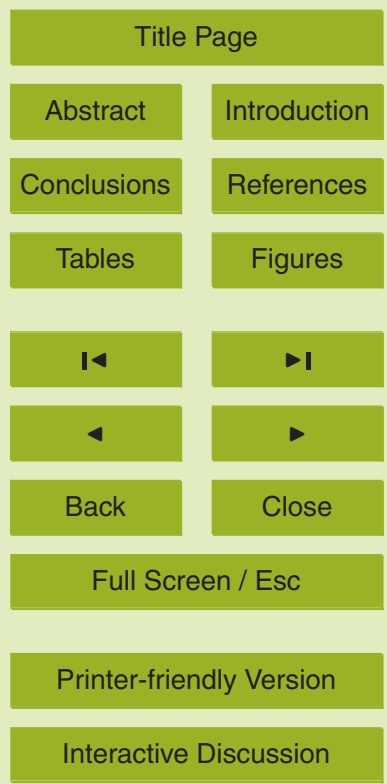


without air bubbling is illustrated in Fig. $8 a$ and b, respectively. The initial fluid supersaturation state with respect to nesquehonite, the first precipitating phase, ranged from 0.2 to 0.6 , at the beginning of the experiments, then maximized to $0.8-1.6$, before massive mineral precipitation, after which it decreased to $0.1-0.3$. The saturation state 5 of these fluids with respect to dypingite was not calculated owing to lack of relevant thermodynamic data. Experiments with lower $\mathrm{HCO}_{3}^{-}$concentrations and thus a lower degree of supersaturation $(\leq 0.3)$ failed to produce sufficient mineral precipitation for analysis. The abiotic experiments resulted in mineral precipitation only when air bubbling was applied; the stirred no-bubbling experiments failed to precipitate detectable 10 quantities of hydrous $\mathrm{Mg}$ carbonate, despite the fact that $\Omega_{\text {nesquehonite }}$ was similar or even higher than that in the biotic experiments (see Fig. 8b).

Apparent precipitation rates $\left(r_{i}\right)$ were calculated from the first derivative of the fluid phase $\mathrm{Mg}$ concentration with respect to time, from the onset of precipitation to the attainment of constant fluid Mg concentrations using:

$r_{i}=\frac{d c_{\mathrm{Mg}}}{d t}$

where $c_{\mathrm{Mg}}$ stands for the concentration of $\mathrm{Mg}$ in the reactive fluid and $t$ designates time. Experiments performed in the presence of sterile humid air bubbling attained steady-state $\mathrm{Mg}$ concentrations over shorter time periods (12 \pm 3 days) and exhibited approximately twice higher apparent precipitation rates compared to bubbling-free experiments. Under similar environmental conditions (Mg, alkalinity, bubbling regime), the precipitation rate measured in biotic experiment S-Bio-2 was significantly higher than that measured in its abiotic counterpart (experiment S-Abio-1).

\subsubsection{Magnesium isotopic composition}

Mg-isotope analyses were performed on selected samples of experiments S-Bio-1, S-

Bio-2, S-Abio-1, S-Abio-4, and S-Abio-5 where nesquehonite and dypingite were the main precipitated mineral phases. The $\mathrm{Mg}$ isotope compositions for all of the analyzed

\section{BGD}

$8,6473-6517,2011$

Can Mg isotopes be used to trace

cyanobacteriamediated

L. S. Shirokova et al.

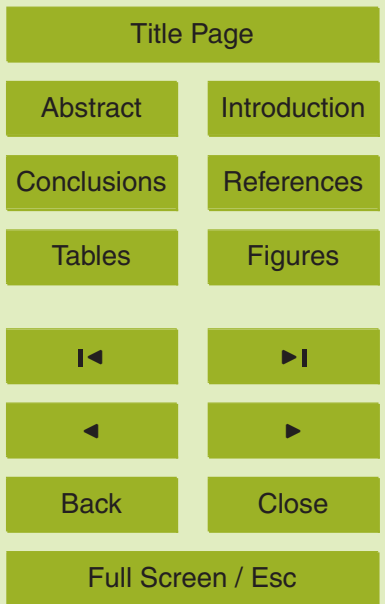

Printer-friendly Version

Interactive Discussion 
samples are given in Table 3, and the evolution of $\delta^{26} \mathrm{Mg}_{\text {solid-solution }}$ during the experiments is plotted in Fig. 9. All of the experiments exhibited mass-dependent fractionation between the liquid and the solid phase. The precipitated hydrous $\mathrm{Mg}$ carbonates had $\delta^{26} \mathrm{Mg}$ compositions that were $0.5-1.4 \%$ olighter than their liquid counterparts, 5 whilst the precipitated brucite was only $0.1-0.2 \%$ o lighter than the aqueous solution. The isotopic composition of Synechoccocus sp. cells from the mineral-free experiment was found to be $0.15 \%$ o heavier than the growth medium.

Based on analysis of solution chemical and isotopical composition, there was no evidence for any relationship between the extent of $\mathrm{Mg}$ fractionation and the fluid $10 \mathrm{pH}, \mathrm{IAP}_{\text {hydromagnesite }}, \mathrm{Mg}$, alkalinity and biomass concentrations. Generally, during the course of experiments in which a single mineral hydrous $\mathrm{Mg}$ carbonate phase was precipitated (e.g. S-Bio-5, S-Abio-1), the $\Delta^{26} \mathrm{Mg}_{\text {solid-liquid }}$ values were found to remain constant (see Fig. 9a, b).

\section{Discussion}

\subsection{Comparison of Lake Salda sediments and laboratory precipitates}

Although stromatolites from Lake Salda have been extensively studied in the past, the present study confirmed the dominance of hydromagnesite $\left(\mathrm{Mg}_{5}\left(\mathrm{CO}_{3}\right)_{4}(\mathrm{OH})_{2} 4 \mathrm{H}_{2} \mathrm{O}\right)$ as the main mineral of these microbialites. The external surface of stromatolites had an extremely porous, void-like, honeycomb-like structure reflecting the presence of bacin the lake littoral sediments and in live microbialites confirmed its long-term stability in the lake water. This observation agrees with reports of hydromagnesite's dominance in alkaline playas of British Columbia (Power et al., 2009) and the persistence of hydromagnesite in other alkaline lake sediments (Renaut and Long, 1989; Queralt et al., 25 1997).

\section{BGD}

$8,6473-6517,2011$

Can Mg isotopes be used to trace

cyanobacteriamediated

L. S. Shirokova et al.

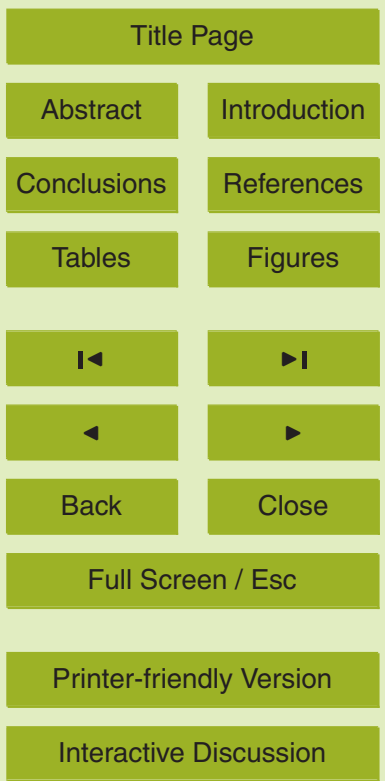


The bottom waters of the lake and the incoming streams were undersaturated with respect to hydromagnesite and nesquehonite, which suggests the importance of both (i) microbial photosynthetic activity and (ii) surface temperature in creating the fluid supersaturation necessary for mineral precipitation.

5 In contrast to the natural samples, experiments produced mainly nesquehonite and dypingite in both biotic and abiotic systems. Although the transformation of nesquehonite into hydromagnesite is relatively fast (on the order of weeks) it has only been studied at elevated temperatures (Davies and Bubela, 1973; Hopkinson et al., 2008). These same authors also suggested that dypingite $\left(\mathrm{Mg}_{5}\left(\mathrm{CO}_{3}\right)_{4}(\mathrm{OH})_{2} 5\left(\mathrm{H}_{2} \mathrm{O}\right)\right)$ may rep10 resent an intermediate metastable phase during the transition of nesquehonite to hydromagnesite. This is in agreement with the results of our long-term experiments (SBio-8, S-Bio-9 and S-Bio-10) where the transformation of dypingite to hydromagnesite occurred. This long-term transformation can explain the presence of less stable intermediate phases (e.g. nesquehonite and dypingite) in experiments run at $25^{\circ} \mathrm{C}$ for 15 only 14 to 42 days. Similarly, Power et al. (2007), reported dypingite formation in biotic mesocosm experiments, and nesquehonite formation in abiotic control experiments performed in the presence of a microbial consortia isolated from Atlin Playas, British Columbia, Canada, at a $\mathrm{pH}$ of $\sim 9.5$

A striking similarity was observed between hydrous $\mathrm{Mg}$ carbonates forming at the 20 surface of live stromatolites in Lake Salda (see Fig. 2b) and those precipitating in longterm laboratory experiments in the presence of Gloeocapsa sp. (see Fig. $2 \mathrm{~h}$ ), as well as in numerous field observations (e.g. Fig. 9c and Fig. 11 in Dupraz et al., 2004). Dupraz et al. (2009) observed that discontinuous EPS calcification generates a micropeloidal structure resulting from the presence of coccoid clusters or filamentous bacteria remnants. Furthermore, these authors reported that no precipitation is observed in or on the sheaths of cyanobacteria, and only a negligible precipitation is directly associated with the inner layers of the active filamentous cyanobacteria mats. Instead, precipitation occurs at the uppermost mat layer, which is composed of EPS, empty filamentous bacteria, and coccoids (Gloeocapsa spp.). Results of the present study corroborates
BGD

$8,6473-6517,2011$

Can Mg isotopes be used to trace

cyanobacteriamediated

L. S. Shirokova et al.

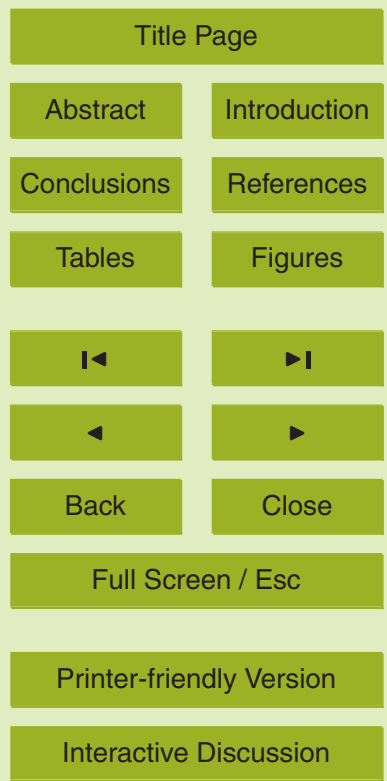


the mechanism of honeycomb - like structure formation via hydrous Mg carbonate precipitation due to the presence of EPS and cell capsules.

The amount of precipitated hydrous $\mathrm{Mg}$ carbonate and biomass production were highly correlated $\left(r^{2} \sim 0.9\right)$ in our laboratory experiments which was consistent with

5 theoretical mineral yield during the biomass production (see Fig. 7). Moreover, the mineral yield due to microbial photosynthesis and, thus, mineral precipitation rates, were very similar among different experiments despite the fact that the experiments were performed in various distinct fluids, durations, biomass concentration, and air bubbling regimes. Given the large variety of investigated conditions, we suggest that 10 the linear relationship shown in Fig. 7 (Eq. 3) can be used for the quantitative prediction $( \pm 25 \%)$ of the amount of hydrous $\mathrm{Mg}$ carbonate precipitation in the presence of photosynthesizing cyanobacteria.

\subsection{The mechanisms of Mg carbonate precipitation in the presence of cyanobacteria}

Carbonate mineral formation in the presence of photosynthetic bacteria has been attributed to the alkaline environment produced due to release of hydroxyl ions as a result of photosynthesis (Thompson and Ferris, 1990; Douglas and Beveridge, 1998). $\mathrm{pH}$ was observed to increase in all experiments, although this increase was almost negligible in abiotic experiments performed without air bubbling. In the abiotic experiments, this $\mathrm{pH}$ increase originated from the degassing of the initial reactive fluid which contained 3-5 $\times 10^{-2} \mathrm{~mol} \mathrm{~kg}^{-1} \mathrm{NaHCO}_{3}$ at $\mathrm{pH} \sim 8.2-9.2$. Owing to this high aqueous bicarbonate content, these initial fluids had a $p \mathrm{CO}_{2}$ of $\sim(0.3-10) \times 10^{-2.0} \mathrm{~atm}$, which is supersaturated with respect to the atmosphere. The bubbling of sterile humid air liberated $\mathrm{CO}_{2}$ from the reactive fluid leading to both an increase in $\mathrm{pH}$ and degree of 25 supersaturation with respect to $\mathrm{Mg}$ carbonate minerals. In the biotic experiments, this $p \mathrm{CO}_{2}$ decrease was accompanied by an additional $\mathrm{pH}$ increase due to photosynthetic uptake of $\mathrm{HCO}_{3}^{-}$ions and $\mathrm{OH}^{-}$release.

Can Mg isotopes be used to trace

cyanobacteriamediated

L. S. Shirokova et al.

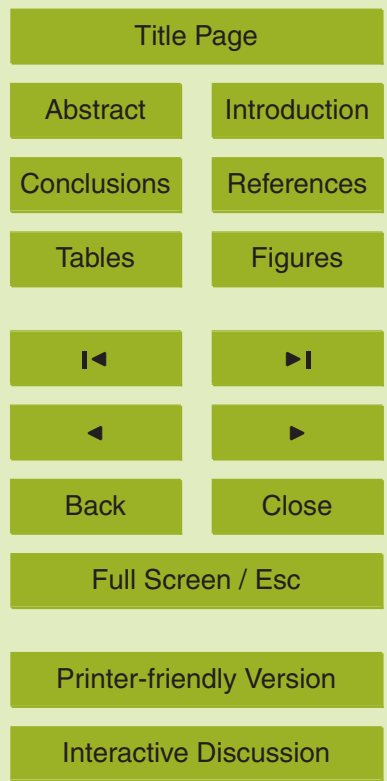


In contrast, the lack of precipitation in abiotic, non-bubbling experiments may stem from insufficient fluid supersaturation occurring in the vicinity of cells during photosynthesis (e.g., Pokrovsky and Savenko, 1994). A significant degree of supersaturation, which can occur in microbial mats due to a local rise in $\mathrm{pH}$ in calcium system 5 (Jorgensen and Revsbech, 1983; Shiraishi et al., 2008), was apparently necessary to initiate nesquehonite precipitation. This increase in supersaturation could not be detectable in our bulk solution $\Omega$ versus time plot (Fig. 8). It seems likely therefore that live photosynthesizing cells may also have acted as nucleation centers due to high local supersaturation in our experiments.

10 Results of the experiments performed in axenic cultures suggest that cyanobacteria increase the $\mathrm{pH}$ of the bulk solution (hence increasing the degree of fluid supersaturation) and provide favorable nucleation sites. Given the presence of microcrystalline mineral precipitates near cell walls and at cell surfaces (see Fig. 3) we suggest that cyanobacterial polysaccharides play a significant role in Mg hydrous carbonate pre15 cipitation. A similar connection was proposed for $\mathrm{Ca}$ carbonate precipitation (e.g., Braissant et al., 2003, 2007; Dittrich and Sibler, 2010). The role of cyanobacterial polysaccharides on $\mathrm{Mg}$ hydrous carbonate precipitation is further confirmed by the similarity of hydrous $\mathrm{Mg}$ carbonate crystals observed in natural microbialites and those grown in laboratory cultures (see Fig. $2 b$ and $h$ ). The capacity of a single culture to precipitate carbonate crystals with a similar form as those of microbial consortia of Lake Salda stromatolites may have important consequences on Mg-rich carbonate formation mechanisms, before the appearance of massive $\mathrm{CaCO}_{3}$ formation in the ocean. If the presence of live cyanobacteria is capable of inducing hydromagnesite precipitation simply by increasing $\mathrm{pH}$ and supersaturation and without specific action of other bacteria, then the formation of Mg-rich stromatolites in the Precambrian could occur via the simplest life forms, before the emergence of complex microbial consortia. This conclusion questions the role in magnesium carbonate precipitation of the postmortem decomposition of cyanobacterial sheaths by heterotrophic bacteria as suggested for ancient dendritic reef structures (Laval et al., 2000).
BGD

$8,6473-6517,2011$

Can $\mathrm{Mg}$ isotopes be used to trace

cyanobacteriamediated

L. S. Shirokova et al.

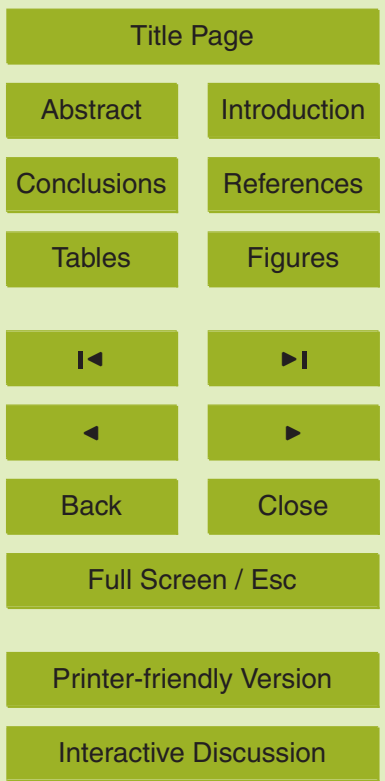


It is widely accepted that actively metabolizing microbial cells can avoid calcium carbonate mineral encrustation and cell entombment (Thompson et al., 1997; Aloisi et al., 2006; Bontognali et al., 2008; Martinez et al., 2010) via cell electric potential regulation, S-layer formation, and extracellular EPS generation (e.g., Krumbein et al., 1977; 5 Chafetz and Buczynski, 1992; Arp et al., 1999a, b; Martinez et al., 2008). Unlike biocalcification (Dupraz et al., 2009; Martinez et al., 2010; Bundeleva et al., 2011), hydrous $\mathrm{Mg}$ carbonate formation does not appear to trigger a cell protection mechanism. The presence of hydrous $\mathrm{Mg}$ carbonate nanoclusters at the surface of live cells, detectable in the TEM images (see Fig. 3a, d, e), and the complete cell encrustation by precipi10 tated mineral seen by the SEM (Fig. $2 \mathrm{~h}$, j) suggests a significant role of the cell surface in governing hydrous $\mathrm{Mg}$ carbonate formation in the presence of cyanobacteria.

An additional difference between calcite versus hydrous $\mathrm{Mg}$ carbonate nucleation at the vicinity of photosynthesizing cells may be the different size of forming crystals. Unlike calcite or dolomite submicron nano-globulles (e.g. Aloisi et al., 2006; Bontognali et 15 al., 2008; Spadafora et al., 2010), the first precipitated hydrous Mg carbonate, nesquehonite, are 50 to $200 \mu \mathrm{m}$ length crystals (Fig. 2l) and as such they cannot encrust the small Synechoccocus. Similarly, rosette-like dypingite crystal aggregates (Fig. 2f, i), formed at the second stage of experiment are also too large to cover completely cyanobacterial cells at the beginning of incrustation. Only at the stage of hydromagnesite formation at the end of experiment (Fig. $2 \mathrm{~h}$, j) does massive embedding and encrusting becomes possible due to (i) the small size of hydromagnesite platelets, and (ii) the presence of dead cells which are easier to mineralize (e.g., Chafetz and Buczynski, 1992; Martinez et al., 2010).

\subsection{Mg isotope fractionation}

25 The extent of $\mathrm{Mg}$ isotope fractionation between cells and aqueous solutions $\left(\delta^{26} \mathrm{Mg}_{\text {solid-solution }}\right)$ due to cell surface adsorption and intracellular uptake during Synechoccocus sp. Growth was equal to $0.152 \%$. This value is similar to the fractionation factor observed during Gloeocapsa sp. cyanobacteria growth (Mavromatis et al., 2011).
BGD

$8,6473-6517,2011$

Can Mg isotopes be used to trace

cyanobacteriamediated

L. S. Shirokova et al.

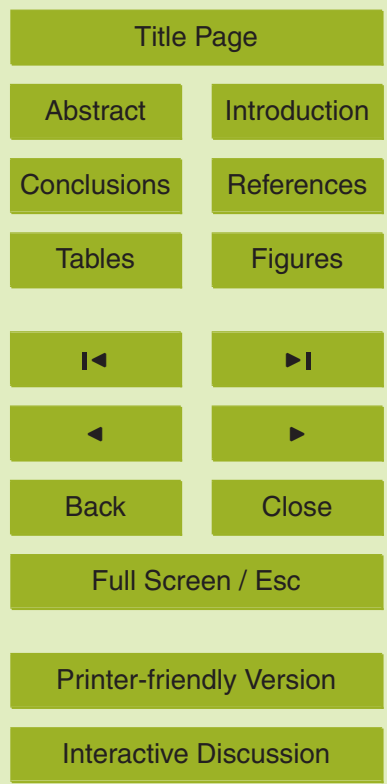


Black et al. (2006) reported that chlorophyll-a, isolated from cyanobacterium S. elongates, preferentially incorporates light $\mathrm{Mg}$ isotopes with a fractionation factor of -0.71 to $-0.53 \%$ o depending on the growth stage. However, the chlorophyll represents small fraction of total cell Mg, compared to the cytoplasm. As such, there may be significant 5 variation of the $\mathrm{Mg}$ isotopic ratio in different cell fractions, with cytoplasm being "heavier" than the chlorophyll. Unlike other essential metals, $\mathrm{Mg}$ is not exchanged during the cell division, but once taken up by the cells, remains inside them (Silver and Walderhaug, 1992). This explains the light Mg isotope composition of mineral-free biomass, collected after 5 days and 3 months (see Table 3).

10 During the abiotic experiment S-Abio-1 in the presence of air bubbling, the precipitated dypingite exhibited a $\delta^{26} \mathrm{Mg}_{\text {solid-solution }}$ value between $-1.4 \%$ and $-1.25 \%$, whereas abiotic experiment S-Abio-4 without bubbling produced only nesquehonite with $\delta^{26} \mathrm{Mg}_{\text {solid-solution }}=-0.47 \%$. In contrast, the biotic experiment with bubbling (experiment S-Bio-5) yielded nesquehonite slightly lighter than its abiotic counterpart and 15 depleted in ${ }^{26} \mathrm{Mg}$ compared to the fluid phase. Finally, biotic experiments produced brucite with $\delta^{26} \mathrm{Mg}_{\text {solid-solution }}=-0.2 \%$ to $-0.1 \%$ o. Overall, we observed a systematic enrichment of minerals by isotopically light $\mathrm{Mg}$ in the order brucite < nesquehonite < dypingite with dypingite fractionation factors similar to that reported for hydrous $\mathrm{Mg}$ carbonates formation in the presence Gloeocapsa sp. cyanobacteria (Mavromatis et al., 2011). The preferential incorporation of light $\mathrm{Mg}$ isotopes in the precipitating solids is consistent with previous $\mathrm{Mg}$ isotope analyses on biogenic skeletal carbonates (Chang et al., 2004; Buhl et al., 2007; Hippler et al., 2009) and abiotically precipitated low Mg-calcite (Galy et al., 2002; Immenhauser et al., 2010).

The $\Delta^{26} \mathrm{Mg}_{\text {solid-liquid }}$ values were almost constant as a function of elapsed time (see 25 Fig. 9a) and the fraction of $\mathrm{Mg}$ remaining in solution (see Fig. 9b). The nearly constant $\Delta^{26} \mathrm{Mg}_{\text {solid-liquid }}$ values for each mineral phase were consistent with a closedsystem equilibrium fractionation model. This suggests a continuous isotopic exchange/equilibration between the precipitated hydrous Mg-carbonates and the reactive fluid (Criss, 1999). Taking into account earlier results for dypingite (Mavromatis
BGD

$8,6473-6517,2011$

Can Mg isotopes be used to trace

cyanobacteriamediated

L. S. Shirokova et al.

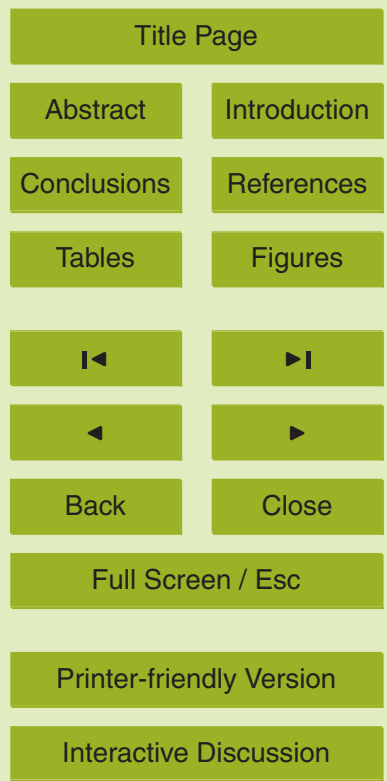


et al., 2011) and for other hydrous Mg carbonates (this work), it can be assumed that hydrous Mg-carbonate minerals are in a continuous isotopic equilibrium with the fluid phase in aquatic environments. This conclusion is consistent with our observations that the precipitated magnesium phase transforms several times during the temporal 5 evolution of each experiment. The exchange does not seem to be appreciably affected by physicochemical factors such as $\mathrm{pH}, \mathrm{pCO}_{2}, \mathrm{Mg}$ and $\mathrm{DIC}$ concentration or biological activity

The isotopic shift between solid and solution observed in the laboratory is in close agreement with that found in the Salda lake ecosystem (see Fig. 10). As Salda lake is 10 a closed basin, assuming the Mg concentration of the lake water is constant, the mass of $\mathrm{Mg}$ arriving to the lake must equal that precipitated in the form of magnesium carbonates. Consequently, mass balance requires that the precipitated hydromagnesite exhibit the same Mg isotopic offset as that between the incoming streams and groundwaters versus the Salda lake water. This is exactly what was observed. A $\delta^{26} \mathrm{Mg}$ offset of $1.0-1.4 \%$ was observed between the Salda lake water and the incoming streams and groundwaters; both naturally forming and laboratory synthesized magnesium carbonates were $1.0-1.4 \%$ o lighter than their corresponding fluid phase. It is important to note that the presence of biofilms and other, heterotrophic bacteria in natural stromatolites apparently, had an insignificant effect on the overall isotopic fractionation factor compared to the laboratory cyanobacteria monocultures.

A very significant observation in this study is that the $\mathrm{Mg}$ isotope fractionation found in abiotic precipitation experiments was nearly identical to that found in biotic experiments and in the natural system. This similarity refutes the use of $\mathrm{Mg}$ isotopes to validate microbial mediated precipitation of hydrous $\mathrm{Mg}$ carbonates. Similar, if our observation of continuous $\mathrm{Mg}$ isotope exchange between hydrous Mg-carbonates and aqueous solutions is general, the Mg-isotopic signature of hydrous $\mathrm{Mg}$-carbonates cannot be used as a paleoproxy tool. Furthermore, assuming that the observed closed isotopic equilibrium indicates a dissolution/re-precipitation process, a similar isotope exchange mechanism for oxygen and carbon may also occur.
BGD

8, 6473-6517, 2011

Can $\mathrm{Mg}$ isotopes be used to trace

cyanobacteriamediated

L. S. Shirokova et al.

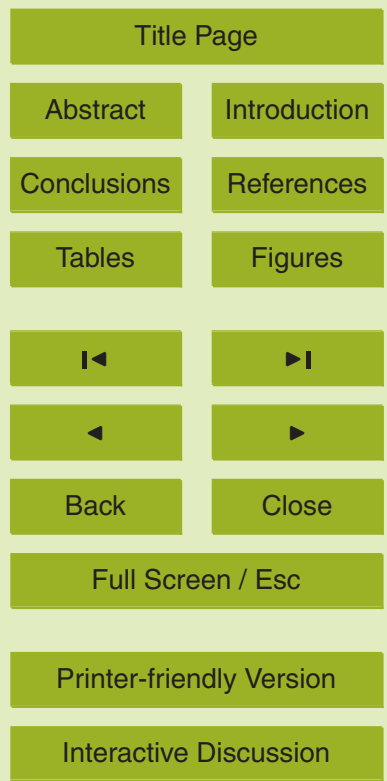




\section{Conclusions}

The hydrochemistry of Lake Salda and field observations suggested a strong microbial control on hydrous $\mathrm{Mg}$ carbonate precipitation in the upper layers of the lake. Laboratory experiments with cyanobacteria culture Chroococales sp. isolated from live stro5 matolite resulted in the precipitation of the hydrous magnesium carbonates nesquehonite and dypingite under various laboratory conditions. We discovered a universal dependence between the amount of $\mathrm{Mg}$ carbonate precipitated and bacterial biomass production, consistent with theoretical ratio of mineral precipitation during photosynthesis. This relationship can be used to reconstruct paleoproductivity based on the amount of accumulated Mg carbonates. All laboratory experiments yielded similar bulk hydrous magnesium carbonate precipitation rates, although the $\mathrm{pH}$ of the reactive fluid was $0.5-1.0$ units higher in biotic compared to abiotic experiments. Taken together these observations suggest that the presence of cyanobacteria is required to increase solution $\mathrm{pH}$ and thus the fluid supersaturation state as well as to provide nucleation sites at the cell surface. No cell protection mechanisms was evident to avoid cells encrusting and entombment by precipitating hydrous Mg carbonates. The difference between the identity of mineral precipitates and solution ${ }^{26} \mathrm{Mg}$ concentration obtained from abiotic experiments were similar within uncertainty of those obtained in the presence of Synechoccocus sp. and in previous experiments performed in the presence 20 of Gloeocapsa sp. cyanobacteria. Considering that similar $\Delta^{26} \mathrm{Mg}_{\text {solid-liquid }}$ values were observed between inflow waters and hydromagnesitic stromatolites of Lake Salda, it can be inferred that a continuous exchange of Mg-isotopes occurred between the solid and liquid phase. This conclusion suggests that the $\mathrm{Mg}$ isotopic composition of hydrous $\mathrm{Mg}$ carbonates cannot be used as a paleoproxy tool.

25 Supplementary material related to this article is available online at: http://www.biogeosciences-discuss.net/8/6473/2011/ bgd-8-6473-2011-supplement.pdf.

Can Mg isotopes be used to trace

cyanobacteriamediated

L. S. Shirokova et al.

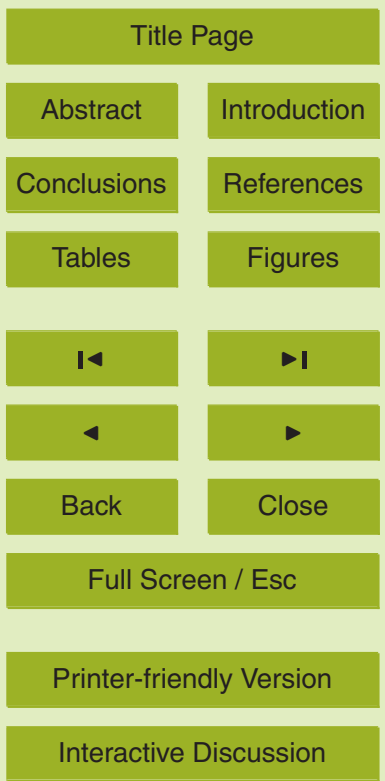


Acknowledgements. Jerome Chmeleff and Carole Causserand are acknowledged for their assistance with the MC-ICP-MS and atomic absorption analyses in Toulouse. This work was supported by ANR $\mathrm{CO}_{2}$-FIX, MC ITN DELTA-MIN (ITN-2008-215360), MC RTN GRASP-CO (MRTN-CT-2006-035868) and MC MIN-GRO (MRTN-CT-2006-035488) and the programs: IN5 TERVIE (INSU), and the Associated European Laboratory LEAGE.

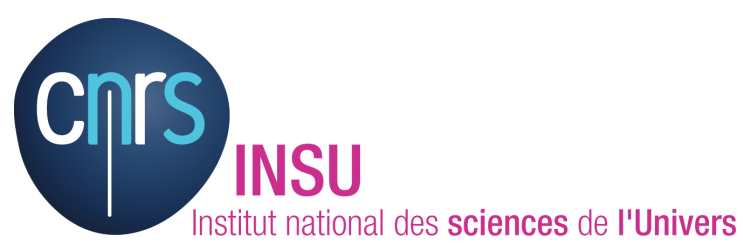

The publication of this article is financed by CNRS-INSU.

\section{References}

Aloisi, G., Gloter, A., Kruger, M., Wallmann, K., Guyot, F., and Zuddas, P.: Nucleation of calcium carbonate on bacterial nanoglobules, Geology, 34, 1017-1020, 2006.

Arp, G., Reimer, A. and Reitner, J.: Calcification in cyanobacterial biofilms of alkaline salt lakes, Eur. J. Phycol. 34, 393-403, 1999a.

Arp, G., Thiel, V., Reimer, A., Michaelis, W., and Reitner, J.: Biofilm exopolymers control microbialite formation at thermal springs discharging into the alkaline Pyramid Lake, Nevada, USA, Sedimentary Geology, 126, 159-176, 1999b.

Bontognali, T. R. R., Vasconcelos, C., Warthmann, R. J., Dupraz, C., Bernasconi, S. M. and McKenzie, J. T.: Microbes produce nanobacteria-like structures, avoiding cell entombment, Geology, 36, 663-666, doi:10.1130/G24755A.1, 2008.

Black, J. R., Yin, Q. Z., and Casey, W. H.: An experimental study of magnesium-isotope fractionation in chlorophyll-a photosynthesis, Geochim. Cosmochim. Acta, 70, 4072-4079, 2006.

Black, J. R., Yin, Q.-Z., Rustad, J. R., and Casey, W. H.: Magnesium-isotope equilibrium in chlorophylls, J. Am. Chem. Soc. 129, 8690-8691, 2007.

25 Brady, A. L., Slater, G., Laval, B., and Lim, D. S.: Constraining carbon sources and growth 6497
BGD

$8,6473-6517,2011$

Can Mg isotopes be used to trace

cyanobacteriamediated

L. S. Shirokova et al.

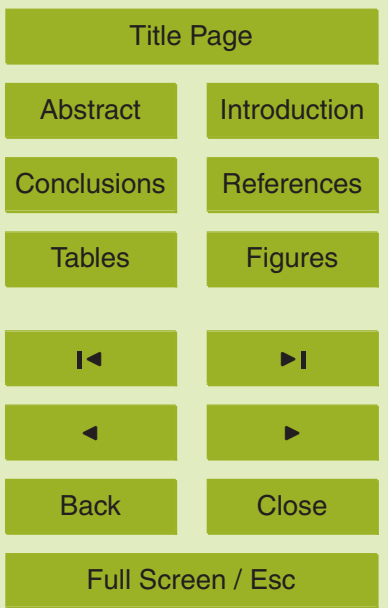

Printer-friendly Version

Interactive Discussion 
rates of freshwater stromatolites in Pavilion Lake using ${ }^{14} \mathrm{C}$ analysis, Geobiology, 7, 544555, 2009.

Braissant, O., Cailleau, G., Dupraz, C., and Verrecchia, A. P.: Bacterially induced mineralization of calcium carbonate in terrestrial environments: The role of exopolysaccharides and amino $5 \quad$ acids, J. Sediment. Res., 73, 485-490, 2003.

Braissant, O., Decho, A. W., Dupraz, C., Glunk, C., Przekop, K. M., and Visscher, P. T.: Exopolymeric substances of sulfate-reducing bacteria: Interactions with calcium at alkaline $\mathrm{pH}$ and implication for formation of carbonate minerals, Geobiology 5, 401-411, 2007.

Braithwaite, C. J. R. and Zedef, V.: Living hydromagnesite stromatolites from Turkey, Sediment. Geol., 92, 1-5, 1994.

Braithwaite, C. J. R. and Zedef, V.: Hydromagnesite stromatolites and sediments in an alkaline lake, Salda Gölü, Turkey, J. Sed. Res. 66, 991-1002, 1996.

Bundeleva, I. A., Shirokova, L. S., Bénézeth, P., Pokrovsky, O. S., Kompantseva, E. I., and Balor, S.: Zeta potential of anoxygenic phototrophic bacteria and $\mathrm{Ca}$ adsorption at the cell surface:

15 Possible implications for cell protection from $\mathrm{CaCO}_{3}$ precipitation in alkaline solutions, J. Coll. Interface Sci., 360, 100-109, 2011.

Buhl, D., Immenhauser, A., Smeulders, G., Kabiri, L., and Richter, D. K.: Time series $\delta^{26} \mathrm{Mg}$ analysis in speleothem calcite: Kinetic versus equilibrium fractionation, comparison with other proxies and implications for palaeoclimate research, Chem. Geol., 244, 715-729, 2007.

Calvin, W. M., King, T. V. V., and Clark, R. N.: Hydrous carbonates on Mars? evidence from Mariner 6/7 infrared spectrometer and ground-based telescopic spectra, J. Geophys. Res., 99, 14659-14675, 1994.

Castanier, S., Âernet-Rollande, M.-C., Maurin, A. and Perthuisot, J.-P.: Effects of microbial activity on the hydrochemistry and sedimentaology of Lake Logipi, Kenya, Hydrobiologia, 267, 99-112, 1993.

Chafetz, H. S. and Buczynski, C.: Bacterially induced lithification of microbial mats, Palaios, 7, 277-293, 1992.

Chang, V. T. C., Williams, R. J. P., Makishima, A., Belshawl, N. S., and O'Nions, R. K.: Mg and $\mathrm{Ca}$ isotope fractionation during $\mathrm{CaCO}_{3}$ biomineralisation, Biochem. Biophys. Res. Commun., 323, 79-85, 2004.

Cox, G., James, J. M., Leggett, K. E. A., Armstrong, R., and Osborne, L.: Cyanobacterially deposited speleothems: Subaerial stromatolites, Geomicrobiol. J., 7, 245-252, 1989.

BGD

$8,6473-6517,2011$

Can Mg isotopes be used to trace

cyanobacteriamediated

L. S. Shirokova et al.

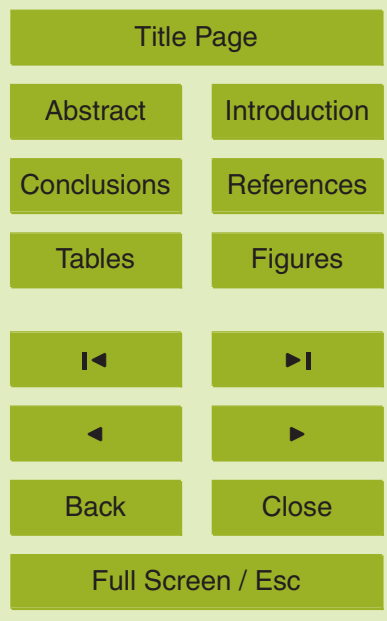

Printer-friendly Version

Interactive Discussion 
Criss, R. E.: Principles of Stable Isotope Distribution, Oxford University Press, Oxford, 254, 1999.

Davies, P. J. and Bubela, B.: The transformation of nesquehonite into hydromagnesite, Chem. Geol., 12, 289-300, 1973.

5 Dittrich, M. and Sibler, S.: Calcium carbonate precipitation by cyanobacterial polysaccharides, in: Tufas and Speleotherms: Unravelling the microbial and physical controls, edited by: Pedley, H. M. and Rogerson, M., Geol. Soc. London Spec. Publ. 336, 51-63, doi:10.1144/SP336.4, 2010.

Dove, P. M.: The Rise of Skeletal Biominerals, Elements 6, 37-42, 2010.

Douglas, S. and Beveridge, T. J.: Mineral formation by bacteria in natural microbial communities, FEMS Microbiol. Ecol. 26, 79-88, 1998.

Dupraz, C., Reid, R. P., Braissant, O., Decho, A. W., Norman, R. S., and Visscher, P. T.: Processes of carbonate precipitation in modern microbial mats, Earth-Sci. Rev., 96, 141-162, 2009.

Dupraz, C., Visscher, P. T., Baumgartner, L. K. and Reid, R. P.: Microbe-mineral interactions: early carbonate precipitation in a hypersaline lake (Eleuthera Island, Bahamas), Sedimentology, 51, 745-765 doi:10.1111/j.1365-3091.2004.00649.x, 2004.

Edwards, H. G. M., Moody, C. D., Newton, E. M., Villar, S. E. J., and Russell, M. J.: Raman spectroscopic analysis of cyanobacterial colonization of hydromagnesite, a putative martian extremophile, Icarus, 175, 372-381, 2005.

Ferris, F. G., Thompson, J. B., and Beveridge, T. J.: Modern freshwater microbialites from Kelly Lake, british Columbia, Canada. Palaios, 12, 213-219, 1997.

Galy, A., Belshaw, N. S., Halicz, L., and O'Nions, R. K.: High-precision measurement of magnesium isotopes by multiple-collector inductively coupled plasma mass spectrometry Internat, J. Mass Spec., 208, 89-98, 2001.

Galy, A., Bar-Mattews, M., Halicz, L., and O'Nions, R. K.: Mg isotopic composition of carbonate: insight from speleotherm formation, Earth Planet. Sci. Lett., 201, 105-115, 2002.

Gérard, E., Moreira, D., Philippot, P., Van Kranendonk, M. J., and López-García, P.: Modern subsurface bacteria in pristine 2.7 Ga-old fossil stromatolite drillcore 30 samples from the Fortescue Group, Western Australia, PLoS ONE, 4(4), e5298, doi:10.1371/journal.pone.0005298, 2009.

Girgin, S., Kazanci, N., and Dügel, M.: On the limnology of deep and saline lake Burdur in Turkey, Acta Hydrochim. Hydrobiol., 32, 189-200, 2004.

BGD

8, 6473-6517, 2011

Can $\mathrm{Mg}$ isotopes be used to trace

cyanobacteriamediated

L. S. Shirokova et al.

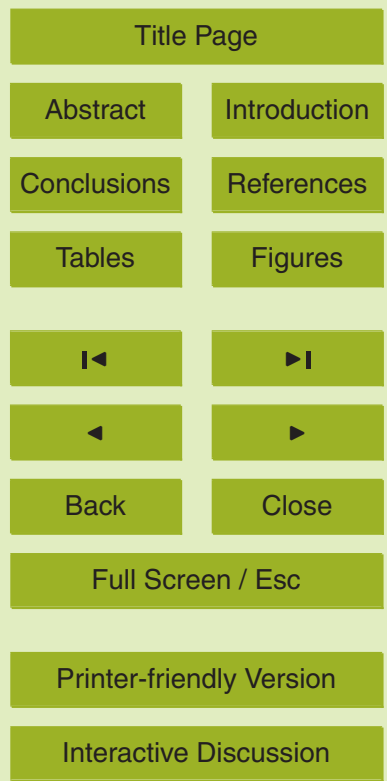


Hartley, A. M., House, W. A., Callow, M. E., and Leadbeater, B. S. C.: The role of a green alga in the precipitation of calcite and the coprecipitation of phosphate in freshwater, Internat. Rev. Hydrobiol. Hydrograph., 80, 385-401, 1995.

Hartley, A. M., House, W. A., Leadbeater, B. S. C., and Callow, M. E.: The use of microelec5 trodes to study the precipitation of calcite upon algal biofilms, J. Colloid Interface Sci., 183, 498-505, 1996.

Higgins, J. A. and Schrag, D. P.: Constraining magnesium cycling in marine sediments using magnesium isotopes, Geochim. Cosmochim. Acta, 74, 5039-5053, 2010.

Hippler, D., Buhl, D., Witbaard, R., Richter, D. K., and Immenhauser, A.: Towards a better understanding of magnesium-isotope ratios from marine skeletal carbonates, Geochim. Cosmochim. Acta, 73, 6134-6146, 2009.

Hopkinson, L., Rutt, K., and Cressey, G.: The transformation of nesquehonite to hydromagnesite in the system $\mathrm{CaO}-\mathrm{MgO}-\mathrm{H}_{2} \mathrm{O}-\mathrm{CO}_{2}$ : An experimental spectroscopic study, J. Geol., 116, 387-400, 2008.

Immenhauser, A., Buhl, D., Richter, D., Niedermayr, A., Riechelmann, D., Dietzel, M., and Schulte, U.: Magnesium-isotope fractionation during low-Mg calcite precipitation in a limestone cave - Field study and experiments, Geochim. Cosmochim. Acta, 74, 4346-4364, 2010.

Jørgensen, B. B. and Revsbech, N. P.: Photosynthesis and structure of benthic microbial mats: Microelectrode and SEM studies of four cyanobacterial communities, Limnol. Oceanogr., 28, 1075-1093, 1983.

Kazanci, N., Girgin, S., and Dügel, M.: On the limnology of Salda Lake, a large and deep soda lake in southwestern Turkey: future management proposals, Aquatic Conservation: Mar. Freshw. Ecosyst., 14, 151-162, doi:10.1002/aqc.609, 2004.

Kazmierczak, J. and Kempe, S.: Genuine modern analogues of Precambrian stromatolites from caldera lakes of Niuafo'ou Island, Tonga, Naturwissenschaften, 93, 119-126, 2006.

Kelts, K. and Hsu, J.: Freshwater carbonate sedimentation, in: Lakes - chemistry, geology, physics, edited by: Lerman, A., Springer, 295-323, 1978.

Kempe, S. and Kazmierczak, J.: Chemistry and stromatolites of the sea-linked Satonda Crater so Lake, Indonesia: A recent model for the Precambrian sea?, Chem. Geol., 81, 299-310, 1990.

Knoll, A. H., Fairchild, J. J., and Sweet, K.: Calcified microbes in Neoproterozoic carbonates: Implications for our understanding of the Proteroizic/Cambrian transition., Palaios, 8, 512-
BGD

8, 6473-6517, 2011

Can Mg isotopes be used to trace

cyanobacteriamediated

L. S. Shirokova et al.

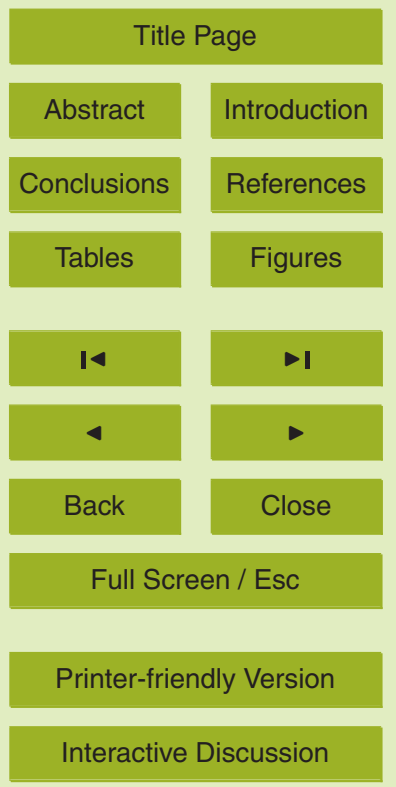


525, 1993.

Kranz, S. A., Wolf-Gladrow, D., Nehrke, G., Langer, G., and Rost, B.: Calcium carbonate precipitation induced by the growth of the marine cyanobacterium Trichodesmium, Limnol. Oceanogr., 55, 2563-2569, 2010.

5 Krumbein, W. E., Cohen, Y., and Shilo, M.: Solar Lake (Sinai), 4., Stromatolitic cyanobacterial mats, Limnol. Oceanogr., 22, 635-656, 1977.

Laval, B., Cady, S. L., Pollack, J. C., McKay, C. P., Bird, J. S., Grotzinger, J. P., Ford, D. C., and Bohm, H. R.: Modern freshwater microbialite analogues for ancient dendritic reef structures, Nature, 407, 626-629, 2000.

$10 \mathrm{Li}, \mathrm{W}$., Beard, B. L., and Johnson, C. M.: Exchange and fractionation of Mg isotopes between epsomite and saturated $\mathrm{MgSO}_{4}$ solution, Geochimica et Cosmochimica Acta, 75, 18141828, 2011.

Lowenstum, H. A. and Weiner, S.: On biomineralization, Oxford University Press, Oxford, New York, 1989.

Martinez, R., Pokrovsky, O. S., Schott, J., and Oelkers, E. H.: Surface charge and zeta-potential of metabolically active and dead cyanobacteria, J. Colloid Interface Sci., 323, 317-325, 2008.

Martinez, R. E., Gardes, E., Pokrovsky, O. S., Schott, J., and Oelkers, E. H.: Do photosynthetic bacteria have a protective mechanism against carbonate precipitation at their surfaces?,

20 Geochim. Cosmochim. Acta ,74, 1329-1337, 2010.

Mavromatis, V., Pearce, C., Shirokova, L. S., Bundeleva, I. A., Pokrovsky, O. S., Benezeth, P., and Oelkers, E. H.: Magnesium isotope fractionation during inorganic and cyanobacteriainduced hydrous magnesium carbonate precipitation, Geochim. Cosmochim. Acta, submitted, 2011.

Müller, G., Irion, G., and Förstner, U.: Formation and diagenesis of inorganic Ca-Mf carbonates in the lacustrine environment, Naturwissenschaften, 59, 158-164, 1972.

Obst, M. and Dittrich, M.: Calcium adsorption and changes of the surface microtopography of cyanobacteria studied by AFM, CFM, and TEM with respect to biogenic calcite nucleation, Gechemistry Geophysics Geosystems, 7, 15, 2006.

30 Obst, M, Wehrli, B. and Dittrich, $\mathrm{M}$.: $\mathrm{CaCO}_{3}$ nucleation by cyanobacteria: laboratory evidence for a passive, surface-induced mechanism, Geobiology, 7, 324-347, 2009.

Oelkers, E. H., Gislason, S. R., and Matter, J.: Mineral carbonation of $\mathrm{CO}_{2}$, Elements, 4, 333338, 2008.

BGD

$8,6473-6517,2011$

Can Mg isotopes be used to trace

cyanobacteriamediated

L. S. Shirokova et al.

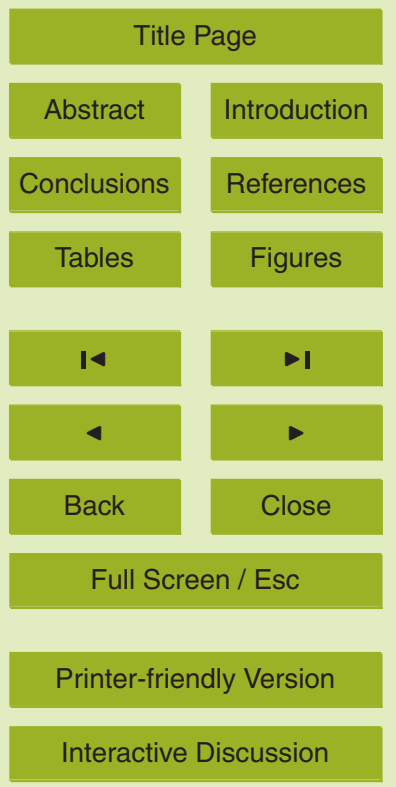

Interactive Discussion 
Otsuki, A. and Wetzel, R. G.: Calcium and total alkalinity budgets and calcium carbonate precipitation in a small hard-water lake, Arch. Hydrobiol. 73, 14-30, 1974.

Palomba, E., Zinzi, A., Cloutis, E. A., D’Amore, M., Grassi, D., and Maturilli, A.: Evidence for Mg-rich carbonates on Mars from a 3.9 $\mu \mathrm{m}$ absorption feature, Icarus, 203, 58-65, 2009.

5 Parkhurst, D. L. and Appelo, C. A. J.: User's Guide to PHREEQC (Version 2) - A Computer Program for Speciation, Batch- Reaction, One-Dimensional Transport, and Inverse Geochemical Calculations, U.S. Geological Survey Water-Resources Investigations Report 99-4259, 310, 1999.

Pedone, V. A. and Folk, R. L.: Formation of aragonite cement by nannobacteria in the Great Salt Lake, Utah. Geology, 24, 763-765, 1996.

Pentecost, A. and Spiro, B.: Stable Carbon and Oxygen Isotope Composition of Calcites Associated with Modern Fresh-Water Cyanobacteria and Algae, Geomicrobiol. J., 8, 17-26, 1990.

Pentecost, A.: Blue-green algae and freshwater carbonate deposits, Proc. R. Soc. London B., $15 \quad 200,43-61,1978$.

Peterson, B. J. and Fry, B.: Stable isotopes in ecosystem studies, Annu. Rev. Ecol. Syst., 18, 293-320, 1987.

Planavsky, N., Reid, R. P., Lyons, T. W., Myshrall, K. L., and Visscher, P. T.: Formation and diagenesis of modern marine calcified cyanobacteria, Geobiology, 7, 566-576, 2009.

20 Pokrovsky, O. S. and Savenko, V. S.: Experimental modeling of $\mathrm{CaCO}_{3}$ precipitation at the conditions of photosynthesis in seawater, Oceanology, 35, N6, 805-810, 1995.

Pokrovsky, O. S., Martinez, R., Golubev, S. V., Kompantzeva, E. I., and Shirokova, L. S.: Adsorption of metals and protons on Gloeocapsa sp. cyanobacteria: a surface speciation approach, Applied Geochemistry, 23, 2574-2588, 2008.

Pokrovsky, O. S., Viers, J., Shirokova, L. S., Shevchenko, V. P., Filipov, A. S. and Dupré, B.: Dissolved, suspended, and colloidal fluxes of organic carbon, major and trace elements in Severnaya Dvina River and its tributary, Chem. Geol., 273, 136-149, 2010.

Pokrovsky, O. S., Shirokova, L. S., Kirpotin, S. N., Audry, S., Viers, J. and Dupré, B.: Effect of permafrost thawing on the organic carbon and metal speciation in thermokarst lakes of western Siberia, Biogeosciences, Special issue Siberian Arctic Land-Shelf-Atmosphere Interface, 8, 565-583, doi:10.5194/bg-8-565-2011, 2011.

Power, I. M., Wilson, S. A., Thom, J. M., Dipple, G. M., Gabites, J. E., and Southam, G.: The hydromagnesite playas of Atlin, British Columbia, Canada: A biogeochemical model for $\mathrm{CO}_{2}$

\section{BGD}

8, 6473-6517, 2011

Can $\mathrm{Mg}$ isotopes be used to trace

cyanobacteriamediated

L. S. Shirokova et al.

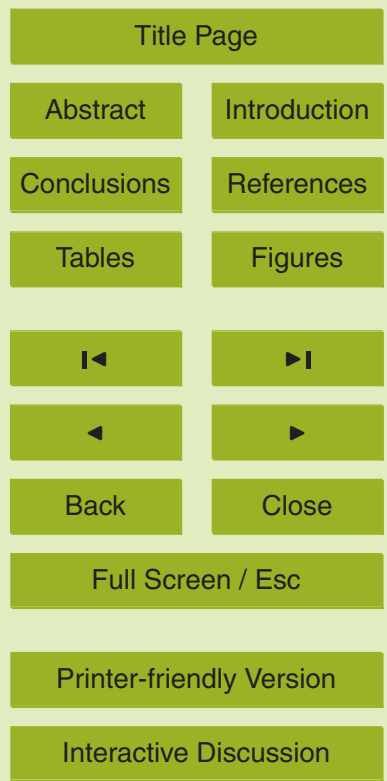


sequestration, Chem. Geol. 260, 286-300, 2009.

Power, I. M., Wilson, S. A., Thom, J. M., Dipple, G. M., and Southam, G.: Biologically induced mineralization of dypingite by cyanobacteria from an alkaline wetland near Atlin, British Columbia, Canada, Geochem. Trans., 8(13), doi:10.1186/1467-4866-8-13, 2007.

5 Power, I. M., Wilson, S. A., Dipple, G. M., and Southam, G.: Modern carbonate microbialites from an asbestos open pit pond, Yukon, Canada, Geobiology, 180-195, doi:10.1111/j.14724669.2010.00265.x, 2011.

Queralt, I., Julia, R., Plana, F., and Bischoff, J. L.: A hydrous Ca-bearing magnesium carbonate from playa lake sediments, Saline Lake, Spain, Amer. Mineral., 82, 812-819, 1997.

10 Raven, J. A. and Giordano, M.: Biomineralization by photosynthetic organisms: Evidence of co-evolution of the organisms and their environment?, Geobiology, 7, 140-154, 2009.

Renault, R.W.: Recent carbonate sedimentation and brine evolution in the saline lake basins of the Cariboo Plateau, British Columbia, Canada, Hydrobiologia, 197, 67-81, 1990.

Renaut R. W. and Long, P. R.: Sedimentaology of the saline lakes of the Cariboo Plateau, 15 Interior British Columbia, Canada, Sed. Geol., 64, 239-264, 1989.

Renaut, R. W. and Stead, D.: Recent Magnesite-Hydromagnesite sedimentation in Playa Basins of the Caribou Plateau, British Columbia, Geological Fieldwork 1990, Paper 19911. British Columbia Geological Survey Branch, 279-288, http://www.em.gov.bc.ca/DL/ GSBPubs/GeoFldWk/1990/279-288-renaut.pdf, 1990.

20 Riding, R.: Microbial carbonates: the geological record of calcified bacterial-algal mats and biofilms, Sedimentology, 47, 179-214, 2000.

Ries, J. B.: Review: geological and experimental evidence for secular variation in seawater $\mathrm{Mg} / \mathrm{Ca}$ (calcite-aragonite seas) and its effects on marine biological calcification, Biogeosciences, 7, 2795-2849, 2010,

25 http://www.biogeosciences.net/7/2795/2010/.

Rippka, R., Deruelles, J., Waterbury, J., Herdman, M., and Stanier, R.: Generic assignments, strain histories and properties of pure cultures of cyanobacteria, J. Gen. Microbiol., 111, 1-61, 1979.

Russell, M. J., Ingham, J. K., Zedef, V., Maktav, D., Sunar, F., Hall, A. J., and Fallick, A. E.: Search for signs of ancient life on mars: expectations from hydromagnesite microbialites, Salda Lake, Turkey, J. Geol. Soc. London, 156, 869-888, 1999.

Schauble, E. A.: First-principles estimates of equilibrium magnesium isotope fractionation in silicate, oxide, carbonate and hexaaquamagnesium(2+) crystals, Geochim. Cosmochim. Acta,

BGD

$8,6473-6517,2011$

Can $\mathrm{Mg}$ isotopes be used to trace

cyanobacteriamediated

L. S. Shirokova et al.

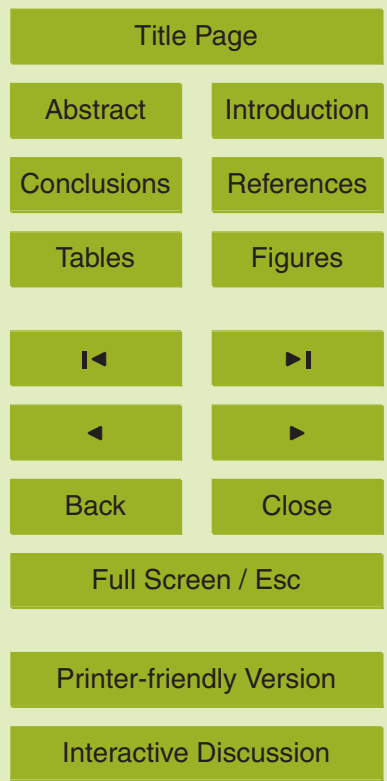


75, 844-869, 2011.

Schmid, I. H.: Turkey's Salda Lake, a generic model of Australia's newly discovered magnesite deposits, Industrial Minerals, 239, 19-31, 1987.

Scholl, D. W. and Taft, W. H.: Algae, contributors to the formation of calcareous tufa, Mono $5 \quad$ Lake, California, J. Sedimentary Research, 34, 309-319, 1964.

Shiraishi, F., Bissett, A., de Beer, D., Reimer, A., and Arp, G.: Photosynthesis, respiration and exopolymer calcium-binding in biofilm calcification (Westerhöfer and Deinschwanger Creek, Germany), Geomicrobiol. J., 25, 83-94, 2008.

Shirokova, L. S., Pokrovsky, O. S., Viers, J., Klimov, S. I., Moreva, O. Yu., Zabelina, S. A., Vorobieva, T. Ya., and Dupré, B.: Diurnal variations of trace elements and heterotrophic bacterioplankton concentration in a small boreal lake of the White Sea basin, Ann. Limnol. Int. J. Lim., 46, 67-75, doi:10.1051/limn/2010011, 2010.

Silver, S. and Walderhaug, M.: Gene regulation of plasmid- and chromosome-determined inorganic ion transport in bacteria, Microbiol. Rev., 56, 195-228, 1992.

15 Spadafora, A., Perri, E., McKenzie, J. A., and Vasconcelos, C.: Microbial biomineralization processes forming modern Ca:Mg carbonate stromatolites, Sedimentology, 57, 27-40, 2010.

Stabel, H.-H.: Calcite precipitation in Lake Constance: Chemical equilibrium, sedimentation, and nucleation by algae, Limnol. Oceanogr., 31, 1081-1093, 1986.

Tipper, E. T., Galy, A., Gaillardet, J., Bickle, M. J., Elderfield, H., and Carder, E. H.: The magnesium isotope budget of the modern ocean: constraints from riverine magnesium isotope ratios, Earth Planet Sci. Lett., 250, 241-253, 2006.

Thompson, J. B. and Ferris, F. G.: Cyanobacterial Precipitation of Gypsum, Calcite, and Magnesite from Natural Alkaline Lake Water, Geology, 18, 995-998, 1990.

Thompson, J. B., Shultze-Lam, S., Beveridge, T. J., and Des Marais, D. J.: Whiting events: 25 Biogenic origin due to the photosynthetic activity of cyanobacterial picoplankton, Limnol. Oceanogr., 42, 133-141, 1997.

Vasyukova, E. V., Pokrovsky, O. S., Viers, J., Oliva, P., Dupré, B., Martin, F., and Candaudaup, F.: Trace elements in organic- and iron-rich surficial fluids of the Boreal zone: Assessing colloidal forms via dialysis and ultrafiltration, Geochim. Cosmochim. Acta, 74, 449-468, 2010. nesite and hydromagnesite deposits in the ultramafic terranes of Southwestern Turkey: A stable isotope study, Econ. Geol., 95, 429-445, doi:10.2113/gsecongeo.95.2.429, 2000.

BGD

8, 6473-6517, 2011

Can Mg isotopes be used to trace

cyanobacteriamediated

L. S. Shirokova et al.

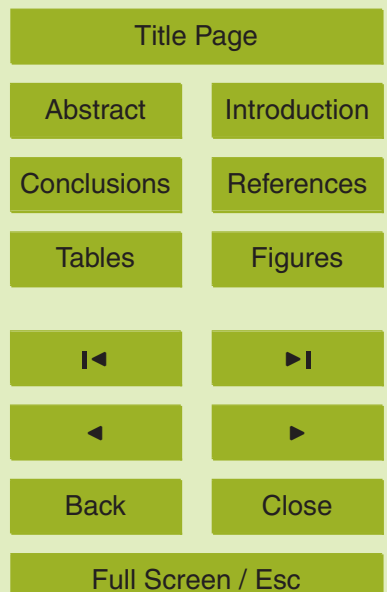

Full Screen / Esc

Printer-friendly Version

Interactive Discussion 
BGD

8, 6473-6517, 2011

Table 1. Experimental conditions of all experiments performed in this study. All abiotic experiments were conducted in the presence of $0.01 \mathrm{M} \mathrm{NaN}_{3}$.

\begin{tabular}{|c|c|c|c|c|c|c|c|c|c|}
\hline Experiment & Medium & $\begin{array}{c}\begin{array}{c}\text { Duration } \\
\text { (days) }\end{array}\end{array}$ & conditions & $\begin{array}{r}\text { Biomass } \\
\text { range, } g_{\text {wet }} / \mathrm{L}\end{array}$ & $\mathrm{pH}$ range & Mg range $(\mathrm{mM})$ & $\begin{array}{r}\mathrm{DOC}, \\
\mathrm{mg} \mathrm{L}^{-1}\end{array}$ & $\begin{array}{l}\text { Rate (Mg slope) } \\
\text { mmol day }^{-1}\end{array}$ & Solid phase \\
\hline S-BIO-1 & BG-11 & 43 & Stirring, no bubbling & $0.1-3.1$ & $8.7-10.6$ & $25.6-2.2$ & $17-62$ & -0.86 & Dypingite+brucite \\
\hline S-BIO-2 & BG-11 & 30 & Stirring, bubbling & $0.2-3.7$ & $8.2-10.5$ & $30.8-4.1$ & 60 & -1.22 & $\begin{array}{l}\text { Nesquehonite, } \\
\text { Dypingite, brucite }\end{array}$ \\
\hline S-BIO-3 & BG-11 on Salda lake water & 34 & Stirring, no bubbling & $0.2-2.2$ & $9.2-10.8$ & $15-2.5$ & $7-18$ & $-0.38^{*+}$ & Dypingite, hydromagnesite \\
\hline S-BIO-4 & BG-11 on Salda lake water & 36 & Stirring, no bubbling & $0.1-3.0$ & $9.3-10.8$ & $14-3$ & $9-17$ & $-0.435^{* \prime}$ & Dypingite, hydromagnesite \\
\hline S-BIO-5 & BG-11 & 30 & Stirring, bubbling & $0.4-2.8$ & $8.2-10.4$ & $31-7$ & 23-29 & -0.71 & Nesquehonite, dypingite \\
\hline S-BIO-6 & Salda lake water w/o BG-11 & 34 & Stirring, no bubbling & $0.2-0.9$ & $9.2-9.6$ & $9.5-12$ & & No precipitation & \\
\hline S-BIO-7 & $0.05 \mathrm{M} \mathrm{MgCl} 2+0.005 \mathrm{M} \mathrm{NaHCO} 3$ & 31 & Stirring, bubbling & $0.05-3.0$ & $8.1-10.0$ & $52-40$ & & No precipitation & \\
\hline S-BIO-8* & BG-11: $0.025 \mathrm{M} \mathrm{MgCl}_{2}+0.036 \mathrm{M} \mathrm{NaHCO}_{3}$ & 100 & No stirring, no bubbling & $0.05-4.0$ & $8.4-10.4$ & $25-5$ & $20-120$ & N.D. & Hydromagnesite \\
\hline S-BIO-9 & BG-11: $0.025 \mathrm{M} \mathrm{MgCl}_{2}+0.036 \mathrm{M} \mathrm{NaHCO}_{3}$ & 100 & No stirring, bubbling & $0.05-3.5$ & $8.4-10.7$ & $25-5$ & $10-65$ & N.D. & Hydromagnesite \\
\hline S-BIO-10 & BG-11: $0.025 \mathrm{M} \mathrm{MgCl}_{2}+0.036 \mathrm{M} \mathrm{NaHCO}_{3}$ & 100 & No stirring, no bubbling & $0.05-3.5$ & $8.5-10.8$ & $25-5$ & $10-40$ & N.D. & Hydromagnesite \\
\hline S-BIO-11* & BG-11: $0.025 \mathrm{M} \mathrm{MgCl}_{2}+0.05 \mathrm{M} \mathrm{NaHCO}_{3}$ & 40 & Stirring, no bubbling & $0.2-2.2$ & $8.7-10.6$ & $25-4$ & $6.2-90$ & N.D. & Dypingite, brucite \\
\hline S-ABIO-1 & Supernatant & 25 & Stirring, bubbling & & $8.15-9.3$ & 23-9 & $90-30$ & -0.50 & \\
\hline S-ABIO-2 & BG-11 on Salda lake water & 35 & Stirring, no bubblinh & 0 & $9.2-9.39$ & $13-12$ & 7.4 & No precipitation & \\
\hline S-ABIO-3 & Supernatant & 25 & Stirring, no bubbling & 0 & $8.1-9.25$ & $37-13$ & 30 & -1.39 & Dypingite \\
\hline S-ABIO-4 & $0.05 \mathrm{M} \mathrm{MgCl}_{2}+0.1 \mathrm{M} \mathrm{NaHCO}_{3}$ & 48 & Stirring, no bubbling & 0 & $8.33-8.90$ & $52-27$ & & -0.67 & Nesquehonite, dypingite \\
\hline S-ABIO-5 & BG-11 on Salda lake water & 35 & Stirring, no bubblinh & 0 & $8.2-9.46$ & $21-22$ & & No precipitation & \\
\hline S-ABIO-6 & BG-11 on Salda lake water & 45 & Stirring, no bubbling & 0 & $9.3-9.4$ & $13.1-13.8$ & & No precipitation & \\
\hline
\end{tabular}

${ }^{*}$ Gloeocapsa sp. Culture;

** The rates are significantly lower due to lower initial Mg concentration.
Can $\mathrm{Mg}$ isotopes be used to trace cyanobacteriamediated

L. S. Shirokova et al.

Title Page

Abstract

Introduction

Conclusions

References

Tables

Figures

14

4

Back

Full Screen / Esc

Printer-friendly Version

Interactive Discussion 
BGD

8, 6473-6517, 2011

Can Mg isotopes be used to trace

cyanobacteriamediated

L. S. Shirokova et al.

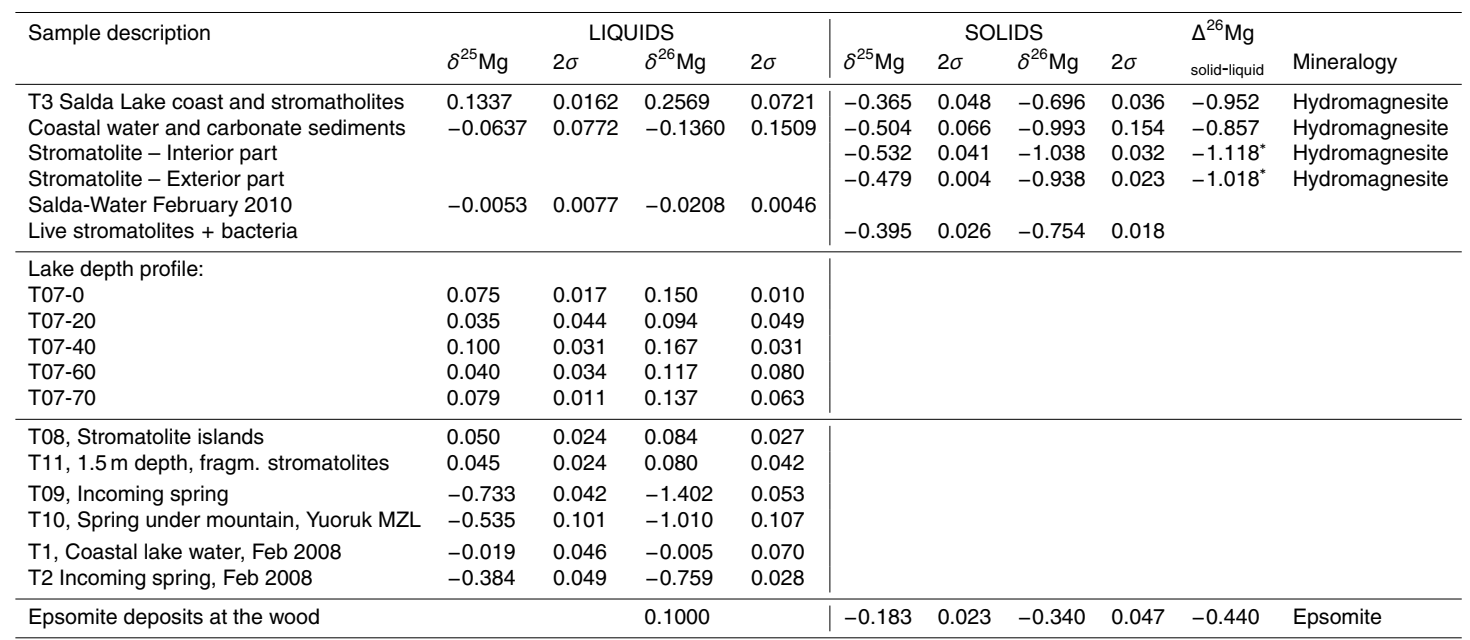

Table 2. Mg isotopic composition of natural samples.

\footnotetext{
${ }^{*}$ Assuming $\delta^{26} \mathrm{Mg}$ in Salda lake water of $0.08 \%$.
}

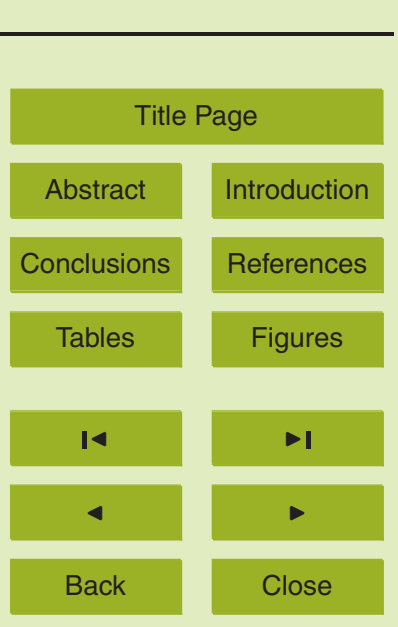

Full Screen / Esc

Printer-friendly Version

Interactive Discussion 
BGD

8, 6473-6517, 2011

Can Mg isotopes be used to trace

cyanobacteriamediated

L. S. Shirokova et al.

\begin{tabular}{crrrrr|rrrrrrr}
\hline Expt. & Sample & Time & \multicolumn{4}{c}{ LIQUIDS } & \multicolumn{4}{c}{ SOLIDS } & \multicolumn{2}{c}{$\Delta^{26} \mathrm{Mg}$} \\
& No. & (Days) & $\delta^{25} \mathrm{Mg}$ & $2 \sigma$ & $\delta^{26} \mathrm{Mg}$ & $2 \sigma$ & $\delta^{25} \mathrm{Mg}$ & $2 \sigma$ & $\delta^{26} \mathrm{Mg}$ & $2 \sigma$ & solid-liquid & Mineralogy \\
\hline S-Bio-1 & 1 & 0 & -0.270 & 0.034 & -0.524 & 0.050 & & & & & & \\
& 8 & 13 & 0.048 & 0.060 & -0.017 & 0.056 & & & & \\
& 13 & 37 & -0.091 & 0.055 & -0.462 & 0.026 & -0.050 & 0.071 & -0.567 & 0.005 & -0.105 & Brucite \\
\hline S-Bio-2 & 6 & 7 & -0.080 & 0.059 & -0.168 & 0.102 & -0.807 & 0.032 & -1.573 & 0.016 & -1.406 & Nesquehonite \\
& 10 & 15 & -0.409 & 0.072 & -0.757 & 0.121 & -0.565 & 0.040 & -1.067 & 0.036 & -0.310 & Dypingite \\
& 14 & 26 & -0.233 & 0.050 & -0.447 & 0.026 & -0.366 & 0.010 & -0.699 & 0.041 & -0.252 & dypingite+brucite \\
& 4 & 6 & -0.074 & 0.041 & -0.103 & 0.033 & -0.738 & 0.016 & -1.428 & 0.005 & -1.325 & Dypingite \\
S-ABIO-1 & 8 & 13 & 0.113 & 0.036 & 0.213 & 0.011 & -0.590 & 0.032 & -1.191 & 0.020 & -1.404 & Dypingite \\
& 13 & 25 & 0.090 & 0.028 & 0.195 & 0.031 & -0.555 & 0.023 & -1.061 & 0.030 & -1.256 & Dypingite \\
\hline S-BIO-5 & 4 & 10 & -0.068 & 0.068 & -0.165 & 0.102 & -0.467 & 0.017 & -0.965 & 0.055 & -0.800 & nesquehonite \\
& 9 & 20 & -0.025 & 0.030 & -0.101 & 0.051 & -0.368 & 0.002 & -0.769 & 0.129 & -0.668 & nesquehonite \\
& 11 & 26 & 0.184 & 0.030 & 0.361 & 0.073 & -0.332 & 0.051 & -0.705 & 0.087 & -1.066 & nesquehonite \\
\hline S-ABIO-4 & 10 & 40 & -0.206 & 0.026 & -0.382 & 0.063 & -0.418 & 0.045 & -0.849 & 0.094 & -0.468 & nesquehonite \\
S-f-5 culture & 5 days & 5 & -0.474 & 0.046 & -0.973 & 0.052 & -0.385 & 0.052 & -0.821 & 0.067 & 0.152 & \\
& 3 months & & & & & & -0.582 & 0.005 & -1.184 & 0.019 & -0.211 & \\
\hline
\end{tabular}

Title Page

Abstract

Introduction

Conclusions

References

Tables

Figures

14

Back

Full Screen / Esc

Printer-friendly Version

Interactive Discussion 

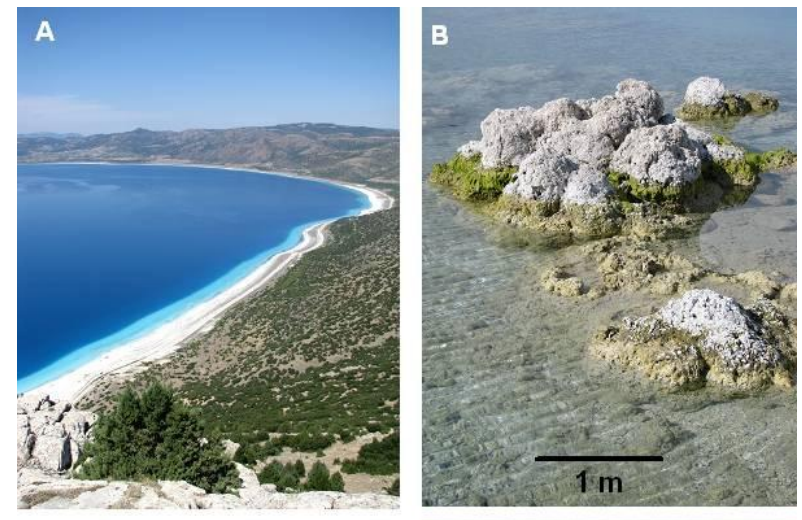

\section{BGD}

$8,6473-6517,2011$

Can Mg isotopes be used to trace

cyanobacteriamediated

L. S. Shirokova et al.
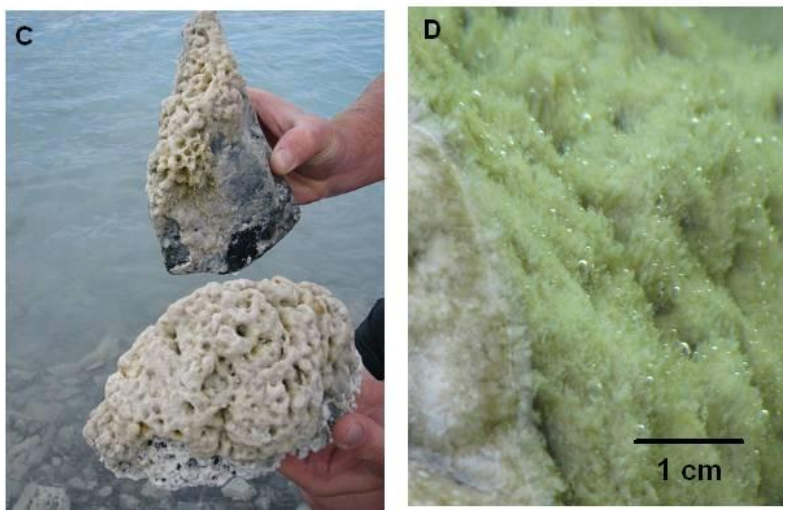

Fig. 1. (A): View of the Salda lake coast. The white and light blue layers in the littoral zone originate from hydromagnesite sand formed due to modern and paleostromatolites wave abrasion. (B): modern stromatolite formations in the littoral zone. (C): stromatolite coatings of the peridote rock debris taken from a depth of 1-1.5 in the littoral zone. (D): the surface of active stromatolite covered by Pyrogira algae and diatoms with oxygen bubbles illustrating active on-going photosynthesis.

Title Page

Abstract

Introduction

Conclusions

References

Tables

Figures

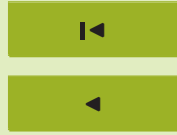

$\rightarrow$ I

Back

Close

Full Screen / Esc

Printer-friendly Version

Interactive Discussion

6508 

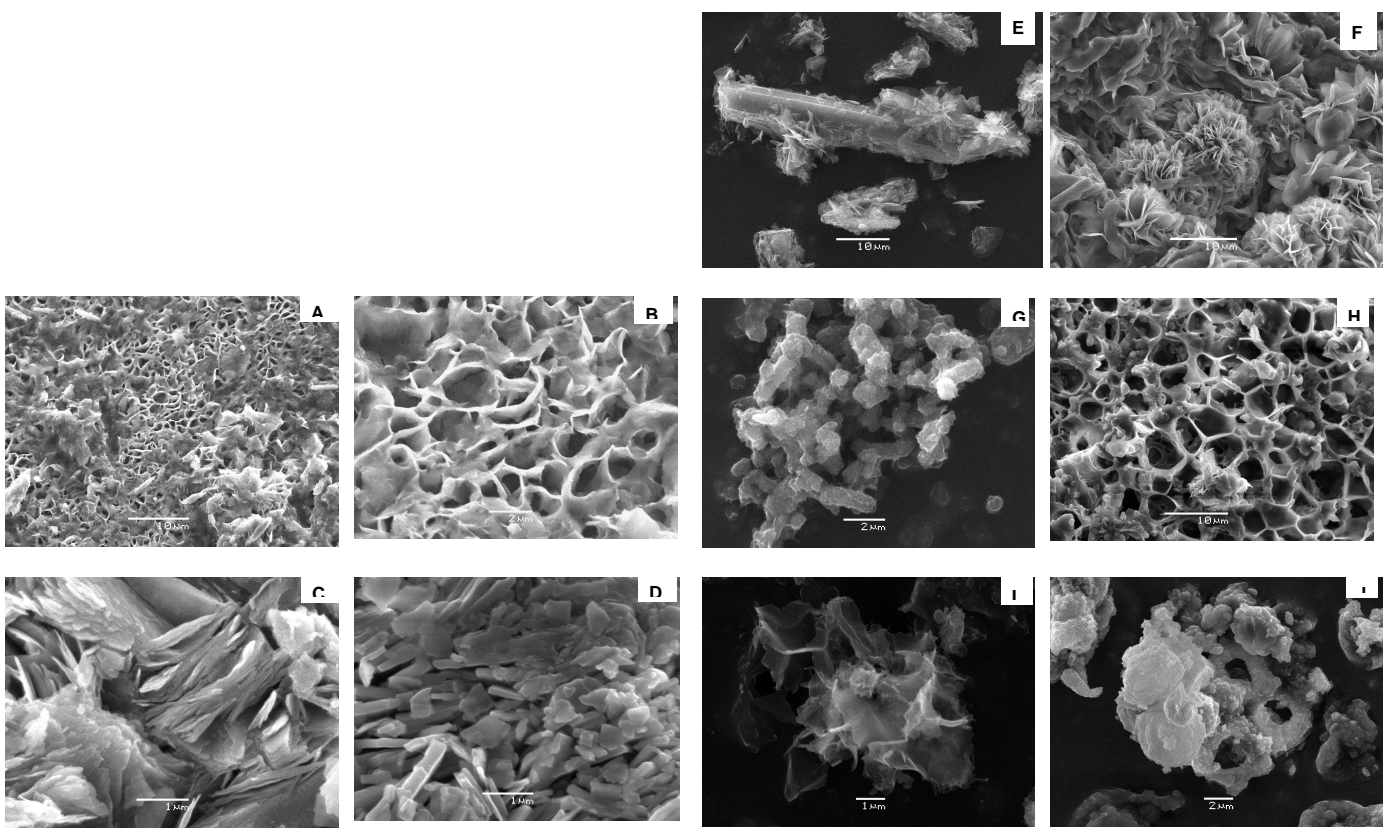

Fig. 2. SEM images of natural stromatolites and experimentally precipitated minerals: (A-D), natural samples; (E-J), laboratory precipitates. (A): Sample T3-1 from the coastal zone, (B) close-up showing the external surface of this stromatolite (C): $2-10 \mathrm{~mm}$ thick mineral coatings taken from grasses and tree branches in the littoral zone water. (D): interior part of the microbialite. EDS analyses demonstrated the presence of only $\mathrm{C}, \mathrm{Mg}$, and $\mathrm{O}$ in all the natural samples shown in A-D. (E-J): nesquehonite and dypingite precipitates recovered from experiment S-Abio-4, (F) dypingite recovered from experiment S-Bio-10, (G), hydromagnesite recovered from experiment S-Bio-3 $(\mathbf{H})$, hydromagnesite recovered from experiment S-Bio-8, (I) dypingite recovered from experiment S-Bio-3, and $(\mathbf{J})$ dypingite and hydromagnesite recovered from experiment S-Bio-11.

BGD

8, 6473-6517, 2011

Can Mg isotopes be used to trace cyanobacteriamediated

L. S. Shirokova et al.

Title Page

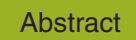

Introduction

Conclusions

References

Tables

Figures

14

- I

4

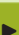

Back

Close

Full Screen / Esc

Printer-friendly Version

Interactive Discussion

6509 

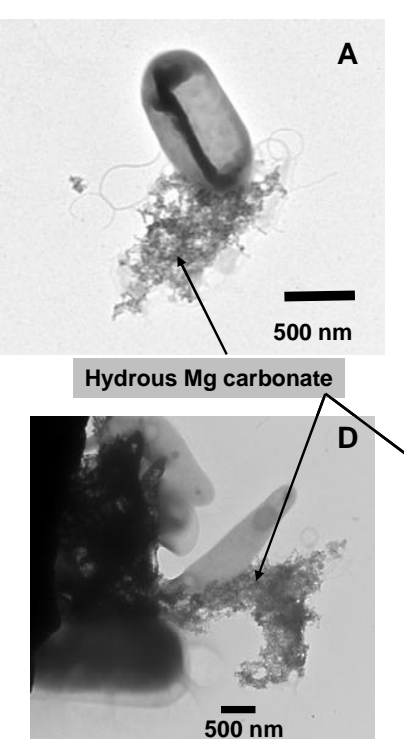

$500 \mathrm{~nm}$

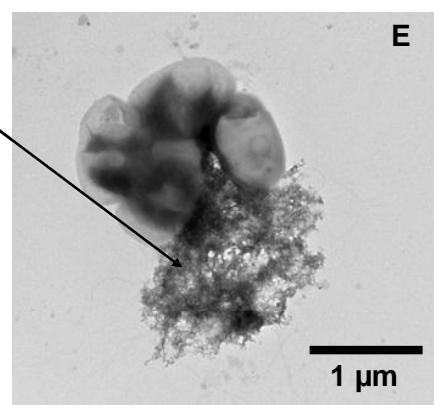

C
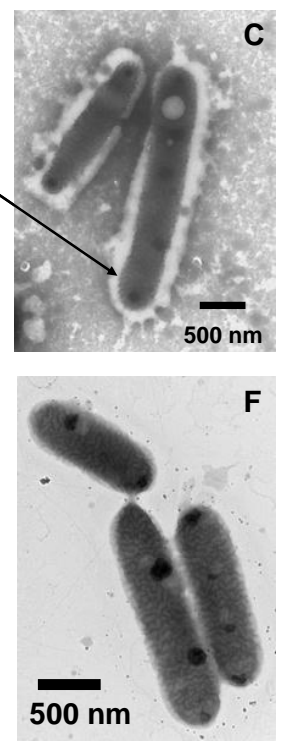

Fig. 3. TEM images of hydrous precipitated $\mathrm{Mg}$ carbonate after 14 days in $0.025 \mathrm{M} \mathrm{MgCl}_{2}+0.05 \mathrm{M} \mathrm{NaHCO}_{3}$ stirred solution without air bubbling (A-E) and Synechococcus $s p$. after its growth during 14 days in BG-11 media without mineral precipitation (F).

\section{BGD}

8, 6473-6517, 2011

Can Mg isotopes be used to trace cyanobacteriamediated

L. S. Shirokova et al.

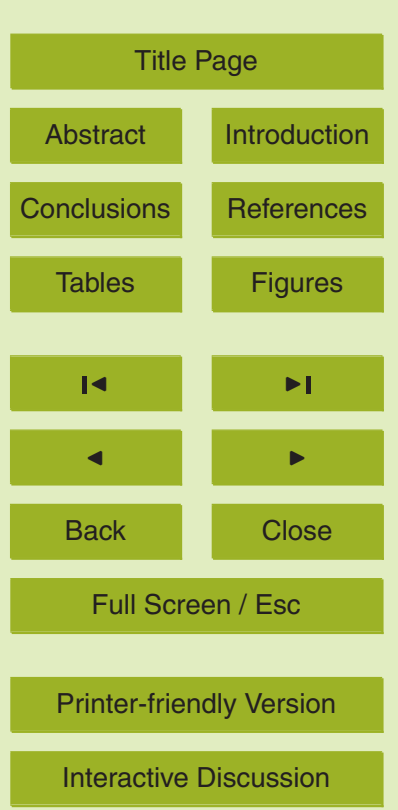



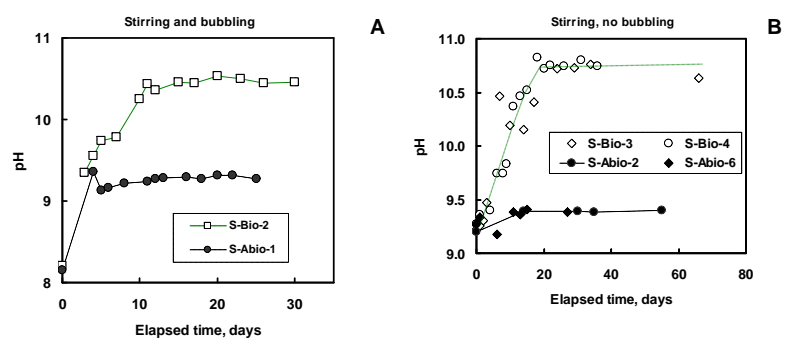

\section{BGD}

8, 6473-6517, 2011

Can Mg isotopes be used to trace cyanobacteriamediated
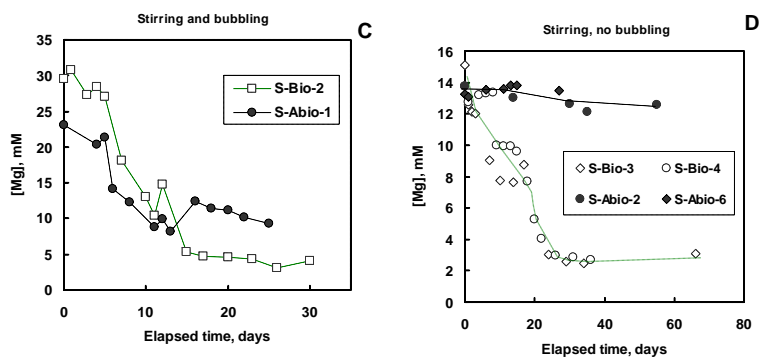

\section{S. Shirokova et al.}
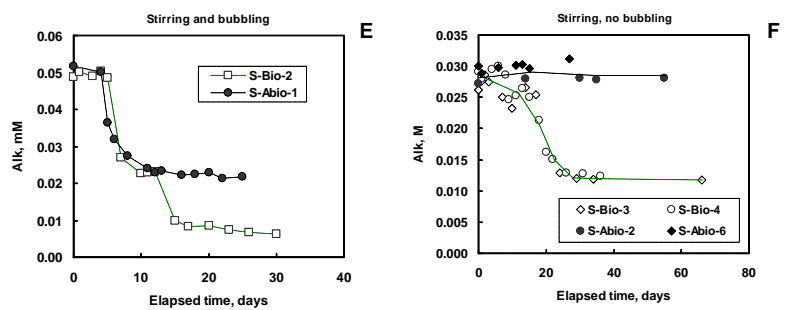

Fig. 4. Reactive fluid evolution during all experiments performed in this study. Temporal evolution of $\mathrm{pH}(\mathbf{A}, \mathbf{B}), \mathrm{Mg}$ concentration $(\mathbf{C}, \mathbf{D})$, and alkalinity $(\mathbf{E}, \mathbf{F})$ during experiments performed in continuously stirred reactors with air bubbling (left panel, A, C, E) and without air bubbling (right panel, B, D, F). The symbol size is encompasses the uncertainty of the analyses. The lines connecting the data points are for the aid of the reader.

Title Page

Abstract

Introduction

Conclusions

References

Tables

Figures

14

4

Back

Close

Full Screen / Esc

Printer-friendly Version

Interactive Discussion 


\section{BGD}

8, 6473-6517, 2011

Can Mg isotopes be used to trace cyanobacteriamediated

L. S. Shirokova et al.

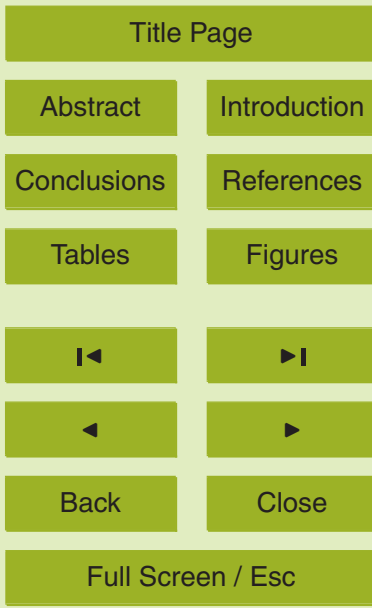

Printer-friendly Version

Interactive Discussion 


\section{BGD}

$8,6473-6517,2011$

Can Mg isotopes be used to trace
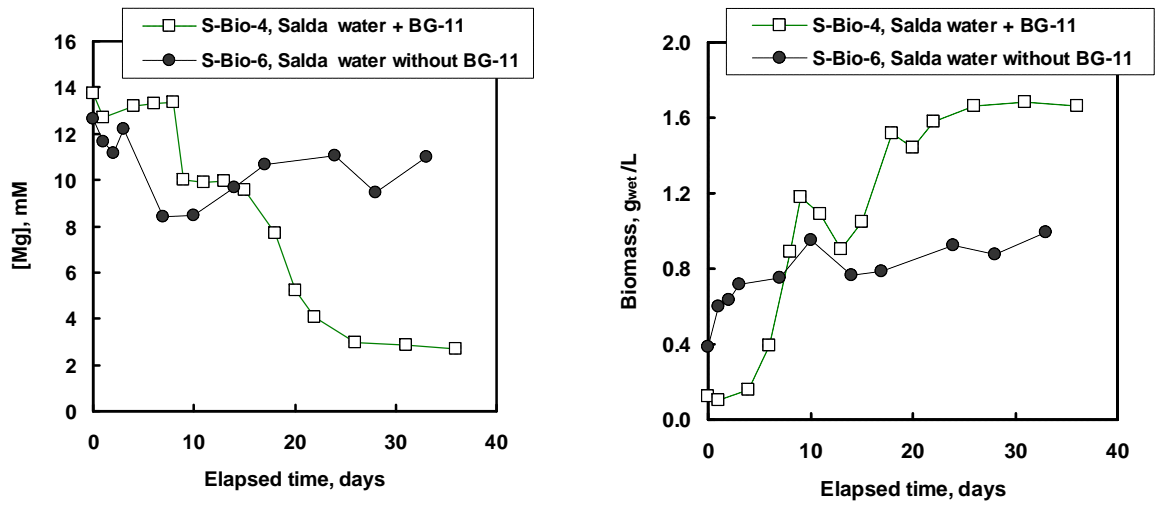

Fig. 6. Magnesium and biomass concentration evolution during experiments in stirred reactors with Salda lake water amended with BG-11 (S-Bio-4, open squares) and without BG-11 components (S-Bio-6, solid circles). The lines connecting the data points are for the aid of the reader. cyanobacteria-

mediated

B

L. S. Shirokova et al.

\section{Title Page}

Abstract

Introduction

Conclusions

References

Tables

Figures

14

- I

4

Back

Close

Full Screen / Esc

Printer-friendly Version

Interactive Discussion 
BGD

8, 6473-6517, 2011

Can Mg isotopes be used to trace cyanobacteriamediated

L. S. Shirokova et al.

\section{Title Page}

Abstract Introduction o S-Bio-4, No bubbling o S-Bio-5, Bubbling $\diamond$ S-Bio-2, Bubbling

Conclusions References $\triangle 4$ 9 $\square$ S-Bio-1, No bubbling $\triangle$ S-Bio-3, No bubbling

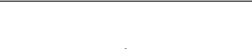

Tables Figures

0

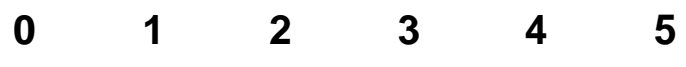

Biomass increase, $g_{w e t}$

Fig. 7. Relationship between the amount of precipitated magnesium $(\mathrm{mmol})$ and the increase of the biomass $\left(g_{\text {wet }}\right)$ in different biotic experiments $\left(r^{2}=0.84-0.93\right)$.

\section{5}

14

4

Back

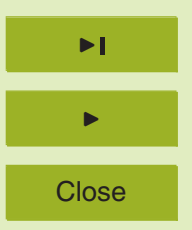

Full Screen / Esc
Printer-friendly Version

Interactive Discussion 


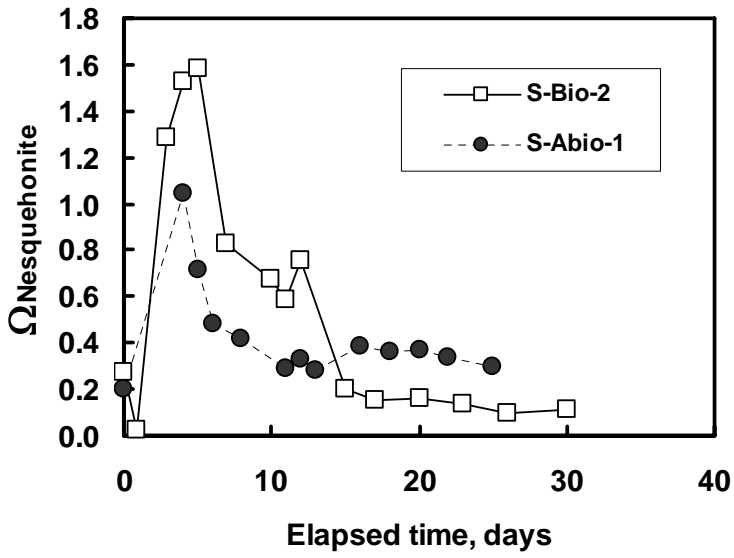

BGD

8, 6473-6517, 2011

Can Mg isotopes be used to trace cyanobacteriamediated

L. S. Shirokova et al.

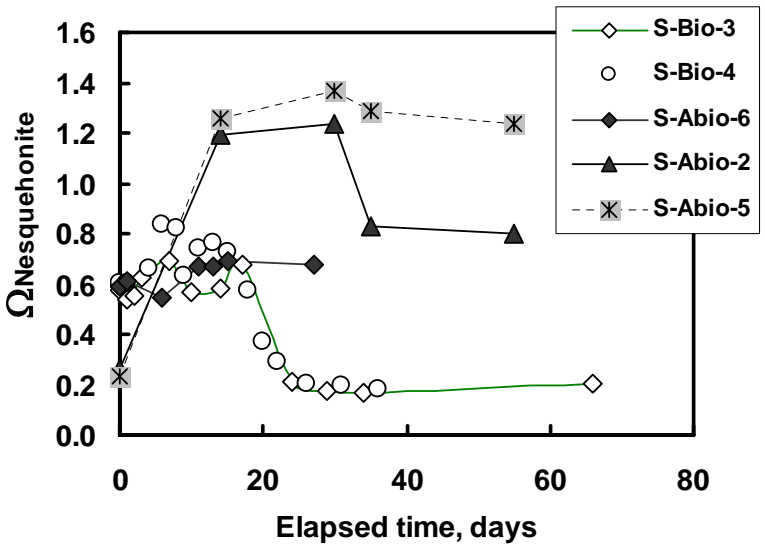

(a)

Title Page

Abstract

Introduction

Conclusions

References

Tables

Figures

14

$\rightarrow$

4

Back

Close

(b)

Full Screen / Esc

Fig. 8. Temporal evolution of degree of saturation of nesquehonite $\left(\Omega_{\text {nesquehonite }}\right)$ of the reactive fluids in stirred experiments. A: During biotic experiment S-Bio-2 and abiotic experiment SAbio-1 with air bubbling; B: During biotic and abiotic experiments without air bubbling. The lines connecting the data points are for the aid of the reader. 
BGD

8, 6473-6517, 2011

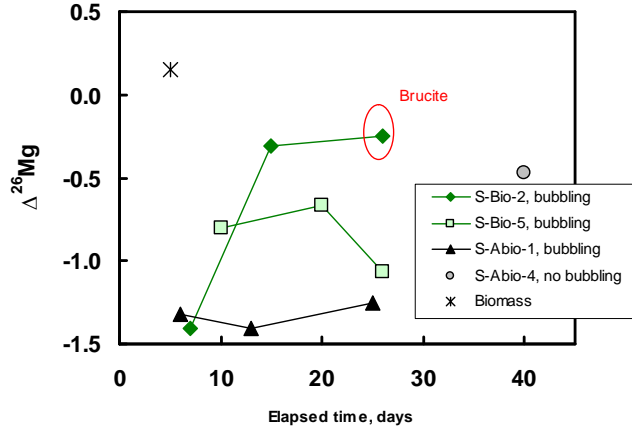

A

Can $\mathrm{Mg}$ isotopes be used to trace cyanobacteriamediated

L. S. Shirokova et al.

Title Page

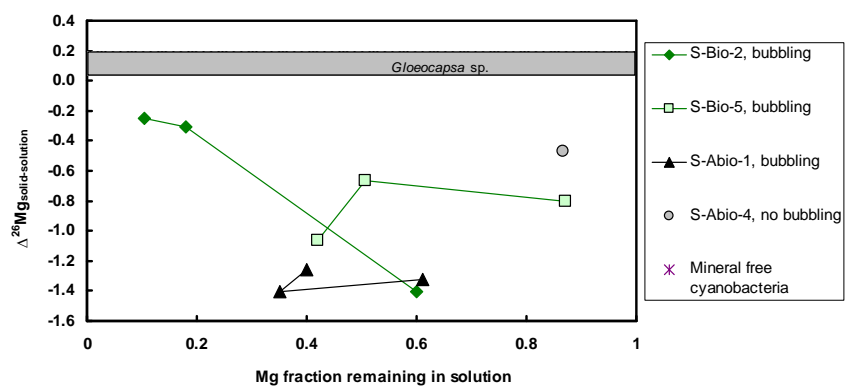

Abstract

Introduction

Conclusions

References

Tables

Figures

14

$\rightarrow$ I

4

Back

Close

\section{Full Screen / Esc}

Printer-friendly Version

Interactive Discussion 
BGD

8, 6473-6517, 2011

Can Mg isotopes be used to trace

cyanobacteriamediated

L. S. Shirokova et al.

Title Page

Abstract

Introduction

Conclusions

References

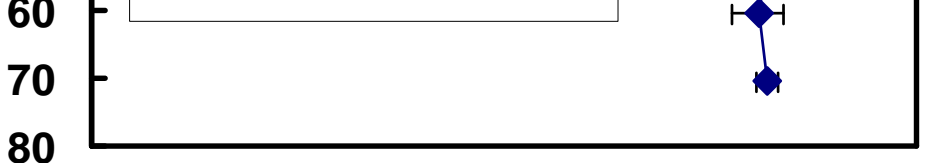

Tables

Figures

$\delta^{26} \mathbf{M g}$, a

Fig. 10. Mg isotopic composition in Salda lake water (blue diamonds), inflowing springs (pink squares), stromatolites and sediments (yellow triangles). 